\title{
Interventions to reduce the impact of unemployment and economic hardship on mental health in the general population: a systematic review
}

\author{
T. H. M. Moore ${ }^{1,2}$, N. Kapur ${ }^{3}$, K. Hawton ${ }^{4}$, A. Richards ${ }^{1,2}$, C. Metcalfe ${ }^{1}$ and D. Gunnell ${ }^{1,2 *}$ \\ ${ }^{1}$ School of Social and Community Medicine, University of Bristol, Bristol, UK \\ ${ }^{2}$ NIHR CLAHRC West, University Hospitals Bristol NHS Foundation Trust, Whitefriars, Lewins Mead, Bristol, UK \\ ${ }^{3}$ Centre for Suicide Prevention, Division of Psychology and Mental Health, The University of Manchester, Manchester, UK \\ ${ }^{4}$ Centre for Suicide Research, Department of Psychiatry, University of Oxford, Warneford Hospital, Headington, Oxford, UK
}

Background. Job loss, debt and financial difficulties are associated with increased risk of mental illness and suicide in the general population. Interventions targeting people in debt or unemployed might help reduce these effects.

\begin{abstract}
Method. We searched MEDLINE, Embase, The Cochrane Library, Web of Science, and PsycINFO (January 2016) for randomized controlled trials (RCTs) of interventions to reduce the effects of unemployment and debt on mental health in general population samples. We assessed papers for inclusion, extracted data and assessed risk of bias.
\end{abstract}

Results. Eleven RCTs ( $n=5303$ participants) met the inclusion criteria. All recruited participants were unemployed. Five RCTs assessed 'job-club' interventions, two cognitive behaviour therapy (CBT) and a single RCT assessed each of emotional competency training, expressive writing, guided imagery and debt advice. All studies were at high risk of bias. 'Job club' interventions led to improvements in levels of depression up to 2 years post-intervention; effects were strongest among those at increased risk of depression (improvements of up to 0.2-0.3 S.D. in depression scores). There was mixed evidence for effectiveness of group CBT on symptoms of depression. An RCT of debt advice found no effect but had poor uptake. Single trials of three other interventions showed no evidence of benefit.

Conclusions. 'Job-club' interventions may be effective in reducing depressive symptoms in unemployed people, particularly those at high risk of depression. Evidence for CBT-type interventions is mixed; further trials are needed. However the studies are old and at high risk of bias. Future intervention studies should follow CONSORT guidelines and address issues of poor uptake.

Received 28 April 2016; Revised 13 October 2016; Accepted 14 October 2016; First published online 15 December 2016

Key words: Anxiety, austerity, debt, depression, financial hardship, intervention, mental health, recession, self-harm, suicide, systematic review, unemployment.

\section{Introduction}

Job loss, debt and financial difficulties are associated with an increased risk of mental illness, self-harm and suicide (Fitch et al. 2011; Haw et al. 2015). During periods of economic recession the numbers of people affected by these and other problems rise and levels of depression, self-harm and suicide increase (Stuckler et al. 2009; Katikireddi et al. 2012; Chang et al. 2013; Corcoran et al. 2015). Interventions to help mitigate the effect of job loss and debt on mental health are an important element of policy response to periods of recession. Ecological studies indicate that factors such as

\footnotetext{
* Address for correspondence: Professor D. Gunnell, School of Social and Community Medicine, University of Bristol, 39 Whatley Road, Bristol BS8 2PS, UK.

(Email: d.j.gunnell@bristol.ac.uk)
}

government spending on active labour market programmes and unemployment protection schemes may counter the effect of recession on suicide rates (Stuckler et al. 2009; Norström \& Grönqvist, 2014) and austerity measures such as reassessment of individuals' eligibility for benefit could have the opposite effect (Barr et al. 2015). However, there have been few evaluations of specific interventions targeted at individuals.

A number of policy documents (WHO, 2011; van Stolk et al. 2014) have summarized some of the limited randomized controlled trial (RCT) evidence of the effects on mental health of interventions for people who have lost their jobs, most notably studies of the JOBS programmes in the USA (Caplan et al. 1989; Vinokur et al. 1995b) and the Työhön job search programme in Finland (Vuori et al. 2002). Two reviews assessed the evidence on 'job search' interventions and included data from randomized and non-randomized

This is an Open Access article, distributed under the terms of the Creative Commons Attribution licence (http://creative commons.org/licenses/by/4.0/), which permits unrestricted re-use, distribution, and reproduction in any medium, provided the original work is properly cited. 
studies (Audhoe et al. 2010; Liu et al. 2014). Both reported that job search interventions improved depression and employment (Audhoe et al. 2010; Liu et al. 2014). However, to our knowledge, no systematic reviews have assessed evidence of the effectiveness of the range of interventions, including job-search programmes, designed to ameliorate the impact of job loss, unemployment and economic hardship on mental health.

Our aim was to systematically review the evidence from randomized controlled trials of interventions given to the general population to reduce the effects of economic hardship on mental health. Our focus was on studies conducted in general population samples of working age individuals, rather than those focusing on specific high-risk samples, such as individuals with serious mental illness (Kukla \& Bond, 2009; Tsang et al. 2010; Burke-Miller et al. 2012; Nieuwenhuijsen et al. 2014). We also excluded studies on select population groups (e.g. single mothers) where we felt policy responses and interventions would be tailored specifically for the particular needs of those populations and were not generalizable to a general population (Wiggins et al. 2004; Forgatch \& DeGarmo, 2007). This review will be of use to policy makers, researchers planning future intervention studies and public health practitioners working in local authorities.

\section{Method}

\section{Criteria for considering studies for this review}

We included randomized controlled trials (RCTs) and cluster randomized trials of public health or health service interventions designed to mitigate the effects of unemployment, debt or austerity measures in the general population. We included only studies with a measure of mental health as an outcome, such as studies with measures of either mental disorder or mental health symptom scales. Examples of types of intervention include: group support or workshops to provide people with job search skills and resilience to the impact of rejected applications; advice type interventions (e.g. Citizens Advice Bureau) to help people navigate their way through benefits systems and/or access relevant support or to provide debt advice; interventions aimed at training frontline staff in job centres or benefits agencies or debt collection agencies to identify individuals who have mental health problems and help them respond appropriately. We excluded studies focused on people with serious mental illness, as this is a distinct subgroup of the population requiring specific intervention types; people not of working age; rehabilitation interventions for people with somatic or mental health problems that either aimed to help them get back into work, or to prevent them from losing their job if they were currently employed; and interventions aimed at selected specific groups of the working population (e.g. single mothers). We also excluded studies if the authors did not report any measure of mental health. A protocol for the review was registered in advance on the PROSPERO website, we prepared the review following Cochrane methods and using PRISMA reporting guidelines (Liberati et al. 2009; Higgins \& Green, 2011; Moore et al. 2015).

\section{Search}

We searched MEDLINE, PsycINFO, Embase on Ovid; the Cochrane Library including CENTRAL on Wiley Interscience; and Science and Social Science Citation Index, and Arts and Humanities Citation Index on Web of Science. All databases were searched from inception to 27 May 2015 and re-run on 16 January 2016. We excluded letters, editorials, and conference proceedings for which there were no full-text papers. We searched the reference lists of, and ran a citation search on, all included studies. We used a combination of MeSH terms and text words for mental health combined with terms for economic hardship, unemployment, job insecurity credit advice and financial worries. We used filters for selection of RCTs taken from the Cochrane Handbook (Lefebvre et al. 2011). We did not exclude studies based on language (see Supplementary Appendix 1 for full details of the searches).

\section{Eligibility, data collection and assessment of risk of bias}

We screened the titles and abstracts and eligibility of full-text reports independently and in duplicate (D.G. and T.H.M.M.) using a form to check the criteria and discussing any discordant decisions until consensus was reached. All authors extracted data and assessed risk of bias, independently and in duplicate, recording these on a data extraction form (D.G., T.H.M.M., K.H., N.K., C.M.). Disagreements were discussed until consensus was reached, with recourse to a third reviewer if necessary. To investigate bias we used the Cochrane Risk-of-Bias tool (Higgins et al. 2011). Domains assessed included quality of the random sequence generation, concealment of allocation, description of drop-outs and withdrawals, blinding (of participants, research personnel and outcome assessment) and selective outcome reporting. (See Supplementary Appendices for details of data extracted, eligibility and risk of bias assessment.) 


\section{Synthesis}

We planned to examine the treatment effect direction and consistency by providing a systematic narrative, structured summary of the evidence (tables and descriptive text) from the studies based on type of intervention and participants. There were insufficient data reported in the studies to prepare a meta-analysis for 'job-club' type interventions; the remaining interventions were too heterogeneous in terms of interventions to attempt to pool data. We categorized type of interventions on a post-hoc basis as described in our protocol because we were unclear what range of interventions, setting and participants we would identify (Moore et al. 2015).

\section{Results}

Our search identified 2389 records (see Fig. 1). The 11 RCTs included 5303 participants and were reported in 26 papers (see Fig. 1). There was considerable heterogeneity in terms of type of intervention, and participants, study size (see Table 1, Fig. 2, Supplementary Appendix 2 and Supplementary Appendix 3). Six studies were from the USA, two from the UK, and one each from Spain, Australia and Finland. Five studies - four in the USA (Caplan et al. 1989; Rife, 1992; Gustafson, 1995; Vinokur et al. 1995b) and one in Finland (Vuori et al. 2002) - examined the effect of 'job-club' type interventions for unemployed people to cope with job loss and assisted them into new employment, two studies assessed the effects of cognitive behavioural therapy (CBT) for unemployed people (Proudfoot et al. 1997; Harris et al. 2002), one study investigated the effects of expressive writing (Spera et al. 1994), a second the effect of guided mental imagery (Joseph \& Greenberg, 2001), and a third the effects of emotional competencies training (Hodzic et al. 2015a). Another study evaluated debt advice for people in debt (Pleasence \& Balmer, 2007).

We excluded 110 reports (see Fig. 1 and Supplementary Appendix 4). Twenty papers describing RCTs were excluded because they did not report any mental health data (see Supplementary Appendix 4); five reports because the population, i.e. single or new mothers on benefits, would necessarily have interventions tailored to suit their circumstances (Wiggins et al. 2004; Forgatch \& DeGarmo, 2007; Morris \& Hendra, 2009; Jagannathan et al. 2010; Kneipp et al. 2011); one report providing loans (Fernald et al. 2008); and two reports where the intervention was increasing access to healthcare insurance (Finkelstein et al. 2012; Baicker et al. 2013), as these interventions were unlikely to be suitable for a general population.
Despite searching for and including people in the general population all participants in the included studies were unemployed, with mean durations of unemployment ranging from 2.3 to 33 months (see Fig. 2). Three studies recruited professionals or management-level staff (Spera et al. 1994; Proudfoot et al. 1997; Pleasence \& Balmer, 2007). Mean age ranged from 32 (Vinokur et al. 1995b) to 58 (Rife, 1992) years and gender balance varied from 13\% male (Hodzic et al. 2015a) to 98\% male (Spera et al. 1994).

Most studies were assessed as at high or unclear 'risk of bias' so the numerical outcomes need to be interpreted with some caution. Information needed to assess bias was not reported in several studies and participants in all 11 studies would have been aware of the intervention they were given and so all the studies were at high risk of bias for that domain (see Fig. 3).

Ten of 11 studies described the personnel delivering the intervention the exception was Rife (1992), while just two, JOBS II and Työhön, described their training (Vinokur et al. 1995b; Vuori et al. 2002). Two studies, JOBS I and JOBS II reported supervision for their staff (Vinokur et al. 1995a, b). Four studies, JOBS I, JOBS II, Työhön and Harris et al. (2002) reported use of a manual (Caplan et al. 1989; Vinokur et al. 1995b; Harris et al. 2002; Vuori et al. 2002) and three (JOBS I, JOBS II and Työhön) included an assessment of fidelity to treatment (Caplan et al. 1989; Vinokur et al. 1995b; Vuori et al. 2002) (see Supplementary Appendix 5).

\section{'Job-club' interventions}

Five studies, reported in 17 papers, assessed the effects of 'job-club' interventions. Four of these compared 'job-club' to written, self-administered job-search materials (JOBS I, JOBS II, Työhön and Gustafson, 1995) and one, Rife et al. compared 'job club' to usual unemployment centre services. The JOBS I intervention (Caplan et al. 1989; Vinokur et al. 1991a, b, 1995a; Price et al. 1992; Vanryn \& Vinokur, 1992) $(n=1122)$ delivered job skills training seminars to groups of 16-20 people in eight sessions of $3 \mathrm{~h}$ (Table 1, Fig. 2 and Supplementary Appendix 3). The JOBS I intervention was modified in JOBS II $(n=1771)$ to focus more on enhancement of personal control, sense of mastery and job-search self-efficacy; sessions were reduced from eight sessions over 2 weeks in JOBS I to daily $4 \mathrm{~h}$ sessions provided over 5 days in JOBS II and training of group facilitators was also increased (Vinokur et al. 1995b, 1996, 2000; Vinokur \& Schul, 1997). Both JOBS I and JOBS II excluded people with any signs of mental illness (JOBS I; Caplan et al. 1989) or depression scores of $>3$ on Hopkins Symptom checklist 90, (JOBS II; Vinokur et al. 1995b) at baseline. Vuori et al. (2002) adapted the JOBS II intervention for use in Finland 

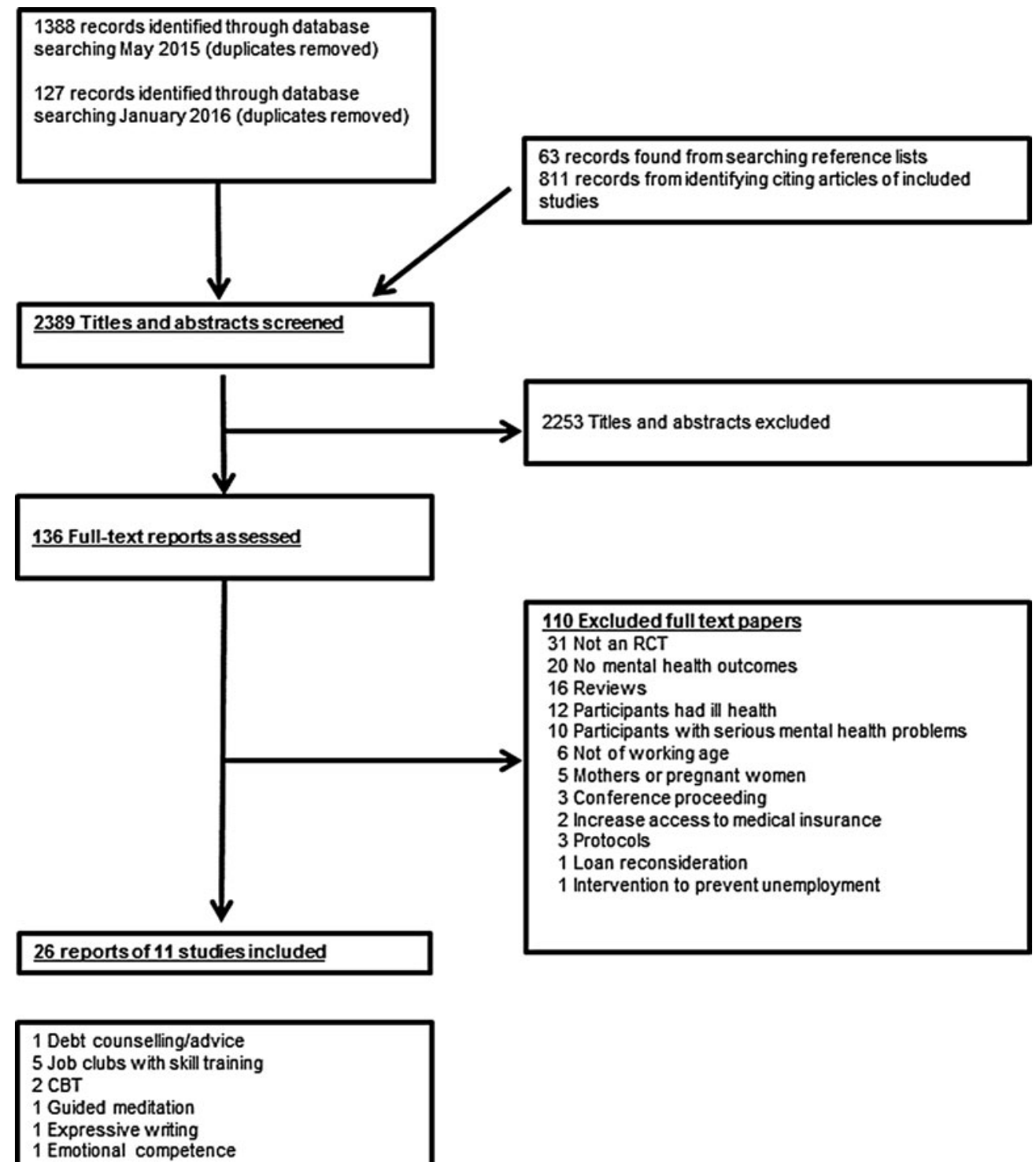

Fig. 1. Study selection.

( $n=1261)$, named it Työhön ('let's get to work'), and recruited people with a longer history of unemployment (11 months v. 3-4 months in JOBS I and JOBS II). Unlike the two JOBS trials a high proportion (78\%) of participants were female (Vuori et al. 2002; Vuori \& Silvonen, 2005; Vuori \& Vinokur, 2005). Rife et al. $(n=52)$ provided practical job skills training workshops two afternoons per week for 12 weeks (Rife, 1992; Rife \& Belcher, 1994) and Gustafson et al. $(n=16)$ delivered job skills training interventions similar to JOBS I for eight $3 \mathrm{~h}$ sessions over 2 weeks (Gustafson, 1995).

The 'job club' intervention delivered in JOBS I had no effect on levels of anxiety or depression at 6 weeks or 4 months (see Table 2). A post-hoc subgroup analysis showed that the participants with higher risk of developing depression, based on the $25 \%$ of participants with highest baseline risk of depression, economic hardship and social assertiveness (Price et al. 1992) benefited most from the intervention (interaction: $p=0.01$ ). In high-risk participants depression scores were reduced at 6 weeks [difference in means: $-0.26,95 \%$ confidence interval $(\mathrm{CI})-0.48$ to -0.04 interaction: $F=6.07 p=0.01], 4$ months (difference in means: $-0.36,95 \% \mathrm{CI}-0.59$ to -0.13 ; interaction: $F=$ $12.14 p=0.001$ ) and 28 months (difference in means: $-0.25,95 \% \mathrm{CI}-0.50$ to 0.0 ; interaction: $F=6.05 p=$ 0.01 ) by up to almost 0.5 s.D. on the depression subscale of the Hopkins Symptom Checklist 90 (HSCL-90; see Table 2). JOBS I had no effect on employment at the same time points (see Table 3) (Caplan et al. 1989; Price et al. 1992; Vinokur et al. 1991a, b, 1995a; Vanryn \& Vinokur, 1992). 
Table 1. Details of interventions and participants

Study ID, country,

design, no. of

arms, no. of

Population age and gender and

participants

ethnicity

Intervention type

Referral pathway and inclusion criteria

Control

JOBS I

Unemployed: $100 \%$

'Job club' (JOBS I)

From four state recruitment compensation offices in SW Michigan

Written material. 25 page booklet on

(Caplan et al. 1989;

(13 of unemployment:

job seeking

1991a, b; Price $\quad$ Maximum 4 months

et al. 1992; vanryn Age: mean 35.9 years (range not

\& Vinokur, 1992; $\quad$ provided)

Vinokur et al. Gender: $46 \%$ male

1995a, b) Ethnicity: $75 \%$ white

USA

RCT 2 arms

$N=1122$

Baseline mental health: not

reported

Class based group active training sessions

with two trainers (male/female pairs)

aiming to cover problem solving, decision

making processes, inoculation against

setbacks, provision of social support and

positive regard from trainers, learning

and practicing job, search skills, building

self-esteem. This intervention aimed to set

itself apart from the work of Azrin et al

(Azrin et al. 1975; Azrin \& Philip, 1979)

$83 \%$ completed

baseline, $88 \%$ at 6

weeks and $80 \%$ at

4 months

Delivered to: people in groups of $16-20$

participants

Duration and frequency: eight $3 \mathrm{~h}$ sessions over 2 weeks

\begin{tabular}{|c|c|c|}
\hline JOBS II & Unemployed: $100 \%$ & ‘Job club' (JOBS II) \\
\hline $\begin{array}{l}\text { (Vinokur et al. } \\
\text { 1995a, b; Vinokur }\end{array}$ & $\begin{array}{l}\text { on of unemployment: mean } \\
\text { veeks S.D. }=3.8 \text { weeks. }\end{array}$ & $\begin{array}{l}\text { JOBS skills training seminars to improve } \\
\text { job seeking }\end{array}$ \\
\hline et al. 1996; & Maximu & ame as JOBS I but with a focus on \\
\hline $\begin{array}{l}\text { Vinokur \& Schul, } \\
\text { 1997; Vinokur }\end{array}$ & $\begin{array}{l}\text { Age: mean } 36.2 \text { years (range not } \\
\text { provided) }\end{array}$ & $\begin{array}{l}\text { increasing sense of mastery, increase of } \\
\text { personal control and job search efficacy. }\end{array}$ \\
\hline et al. 2 & Genc & \\
\hline USA & $\mathrm{E}$ & \\
\hline RCT 2 arms & Base & Ipport \\
\hline$N=1771$ & & \\
\hline $\begin{array}{l}\text { completed } \\
\text { baseline. } 1801\end{array}$ & $\begin{array}{l}\text { leted a } \\
\text { from }\end{array}$ & Ind practicing job seeking skills. \\
\hline $\begin{array}{l}\text { randomized, } 80 \% \\
\text { at } \mathrm{T} 2 ; 87 \% \text { at } \mathrm{T} 3\end{array}$ & $\begin{array}{l}\text { Price et al. (1992) (JOBS I) and a } \\
\text { 'weighting' was applied to } \\
\text { classify people at low or high risk } \\
\text { of poor mental health. JOBS II }\end{array}$ & $\begin{array}{l}\text { Group support, problem solving, trainer } \\
\text { support, active identification of possible } \\
\text { setbacks, planning how to respond to } \\
\text { these and practicing responses }\end{array}$ \\
\hline
\end{tabular}

From four state recruitment compensation offices in South West Michigan
Written, self-administered, job

search materials and pamphlet. 25 page booklet on Job skills and job searching 
then oversampled from those at High risk of poor mental health based on these criteria. This was done because JOBS I found the Job Club intervention appeared to improve depression symptoms of those at higher risk

-

Työhön

Unemployed: $100 \%$

Duration of unemployment:

'Job club': Työhön 'let's get to work' Job

ri et al. 2002;

Vuori \& Vinokur,

2005)

Finland

RCT 2 arms

$N=1261$

randomized, 994

(78\%) completed

median 5 months (

S.D. $=17.3)$. $28 \%$ unemployed for

12 months or longer

Age: mean $=37$ (18-61 years)

Gender: $22 \%$ male

Ethnicity: not reported

Baseline mental health: not

reported
Delivered to: People in groups of $12-20$ participants

Duration and frequency: $5 \times 4 \mathrm{~h}$ sessions over 1 week
Search Program. Based on JOBS I

I and JOBS II is context. Finnish

access to higher rates of unemployment

benefit than US counterparts

Components: class based group active

female pairs) aiming to cover problem
Main difference between this trial and JOBS

unemployed participants have longer

training sessions with two trainers (male/

solving, decision making processes,

inoculation against setbacks, provision of

social support and positive regard from

trainers, learning and practicing job,

search skills, building self-esteem

Delivered to: groups of 6-17 participants

Duration and frequency: daily, half-day sessions over 5 days

(Rife, 1992; Rife \& Unemployed: 100\%. Duration of Belcher, 1994)

USA

RCT 2 arms

$N=52$,

randomized

$100 \%$ completed
'Job club': JOBS skills training seminars to improve job seeking

Provision of practical assistance in

completing forms and CVs and access to

telephones to call potential employers.

Based on work by Gray 1983 and Azrin

1978(Azrin, 1978, Gray, 1983)

Gender: $56 \%$ male

Baseline mental health: mean

Geriatric Depression Scale (GDS

intervention 6.6 control 6.2 .

Participants were reported to be

'mildly depressed'
By post, phone and direct contact from four Written job search materials employment offices by contacting recently

laid-off workers; recruiting services of trade unions, associations of the unemployed, and universities; and by advertisements in newspapers, radio, and the Internet
People who had applied for employment assistance services with the community agency

Usual service: State Government Job Service and community referral programme, e.g. employment registration, information and referral 
Study ID, country,

design, no. of

arms, no. of

Population age and gender and

participants

ethnicity

Intervention type

Referral pathway and inclusion criteria

Control

Groups also provided practical advice and

help on information on job leads, access to

telephones, and support (peer and from

the group leaders)

Duration and frequency: one half day

workshop followed by two afternoon

workshops per week for 12 weeks

\begin{tabular}{ll}
\hline (Gustafson, 1995) & Unemployed: $100 \%$ \\
USA & Duration of unemployment: mean \\
RCT 2 arms & 5.5 months range (1.5-13) \\
$N=16$ & Age: median 36 years (21-50 \\
$100 \%$ completed & years) \\
& Gender: $25 \%$ male \\
& Ethnicity: $88 \%$ white \\
& Baseline mental health Stait \\
& Anxiety: Intervention mean 48.2 \\
& (s.D.=11.8), control mean 41.0 \\
& (s.D.=8.5). Trait anxiety mean 43.6 \\
& (s.D.=14.3), control mean 46.6 \\
& (S.D.=7.5)
\end{tabular}

(Proudfoot et al.

'Job club': based on JOBS I

Components: coping skills, problem

solving, inoculation against setbacks,

social support and positive regard from

trainers, job seeking skills training and

practice, job interview preparation

Delivered to: group of 8 people

Duration and frequency: $8 \times 3 \mathrm{~h}$ sessions

over 2 weeks

1997, 1999)

Unemployed: $100 \%$

Duration of unemployment: for 12

CBT Group CBT

months to 12 years. Mean length of unemployment 25.8 months intervention group and, 23.1

months control group

Age: mean 43 years (22-62 years)

Gender: $83 \%$ male

Ethnicity: not reported

Baseline mental health:

Intervention group: GHQ-30 59\%

scored 5 or more. Control group: identify and test the validity of

automatic thoughts, reattribution of

thoughts, and monitoring behaviour and

experimentation with behaviours. The

CBT included weekly homework

Components: introduction to cognitive

model, goal setting, automatic thoughts,

Though recording, common thinking

errors, techniques to change unhelpful

thinking, personalization of the approach

homework, Final session was to teach

Recruitment from Saddleback college career Written, self-administered, job centre offices, California search materials and pamphlet

Newspaper adverts, mail shots, the UK Employment service, employment/

recruitment organization
Social support programme, same format as CBT and included weekly homework 
GHQ-30 54\% scored of 5 or more (psychiatric caseness) participants to use what they had learned in the future

Delivered to: groups of 10-15 people

Duration and frequency: $3 \mathrm{~h}$ weekly for 7 weeks

\begin{tabular}{|c|c|c|c|c|}
\hline $\begin{array}{l}\text { (Harris et al. 2002) } \\
\text { Australia } \\
\text { RCT } 2 \text { arms } \\
N=195 \\
\text { randomized } \\
100 \% \text { completed }\end{array}$ & $\begin{array}{l}\text { Unemployed: } 100 \% \\
\text { Duration of unemployment: mean } \\
\text { length of unemployment } 33 \\
\text { months (s.D. }=40.0) \\
\text { Age: } 34 \text { years S.D. = } 9.4(18-45 \\
\text { years) } \\
\text { Gender: } 55 \% \text { male } \\
\text { Ethnicity: not reported } \\
\text { Baseline mental health } \\
\text { Intervention SF-36 Mental } \\
\text { Component Scale } 41.03 \text { (15.13), } \\
\text { control } 45.63 \text { (12.35) } \\
\text { Other: long-term unemployed } \\
\text { from disadvantaged areas of } \\
\text { Sydney. } 51 \% \text { left school before } \\
\text { completing higher-level } \\
\text { qualifications }\end{array}$ & $\begin{array}{l}\text { CBT: Group CBT } \\
\text { Cognitive restructuring (identifying } \\
\text { negative thoughts, modifying and } \\
\text { replacing thoughts), problem solving (five } \\
\text { step structured problem solving activity), } \\
\text { behaviour strategies (relaxation skills, } \\
\text { breathing techniques) } \\
\text { CBT was modified during pilot testing } \\
\text { from an existing 3-day CBT programme to } \\
\text { a } 2 \text { day programme } \\
\text { Delivered to: groups of } 5-16 \text { people } \\
\text { Duration and frequency: } 2 \text { days ( } 11 \mathrm{~h} \text { total) }\end{array}$ & $\begin{array}{l}\text { Employment support agencies in } \\
\text { disadvantaged areas of Sydney }\end{array}$ & $\begin{array}{l}\text { Two-day Senior First Aid certificate. } \\
\text { Two-day Senior First Aid } \\
\text { Certificate - fundamental } \\
\text { principles/knowledge/skills of } \\
\text { First Aid } \\
\text { Duration and frequency: Two days } \\
\text { with exam }\end{array}$ \\
\hline $\begin{array}{l}\text { (Pleasence \& } \\
\text { Balmer, 2007) } \\
\text { UK } \\
\text { RCT } 2 \text { arms } \\
N=402 \\
\text { randomized. } \\
234 \text { completed (119 } \\
\text { intervention and } \\
115 \text { control) }\end{array}$ & $\begin{array}{l}\text { Unemployed: 'Mostly } \\
\text { unemployed seeking work' } \\
\text { recruited from job centres } \\
\text { In debt: } 100 \% \text { of participants were } \\
\text { in debt } \\
\text { Age: mean } 35 \text { years (range not } \\
\text { provided) } \\
\text { Gender: not reported } \\
\text { Ethnicity: } 66 \% \text { white } \\
\text { Baseline mental health: not } \\
\text { reported }\end{array}$ & $\begin{array}{l}\text { Debt advice: telephone call from trained } \\
\text { advisors from 'National Debtline' } \\
\text { Where was advice given? By phone } \\
\text { Content: telephone call from National } \\
\text { Debtline. Advice was free of charge. } \\
\text { Immediate advice and assistance was } \\
\text { provided in relation to any emergency } \\
\text { issues, (e.g. bailiffs or repossession). Main } \\
\text { advice was on longer-term resolution of } \\
\text { problems such as debt management } \\
\text { programmes. Written self-help materials } \\
\text { were provided. Participants could be } \\
\text { referred on to other services } \\
\text { Delivered to: individuals } \\
\text { Duration and frequency: one-off telephone } \\
\text { call }\end{array}$ & Researchers approached people in job centres & $\begin{array}{l}\text { No intervention. Usual Job Centre } \\
\text { service }\end{array}$ \\
\hline
\end{tabular}


Study ID, country,

design, no. of

arms, no. of

Population age and gender and

participants

ethnicity

Intervention type

Referral pathway and inclusion criteria

Control

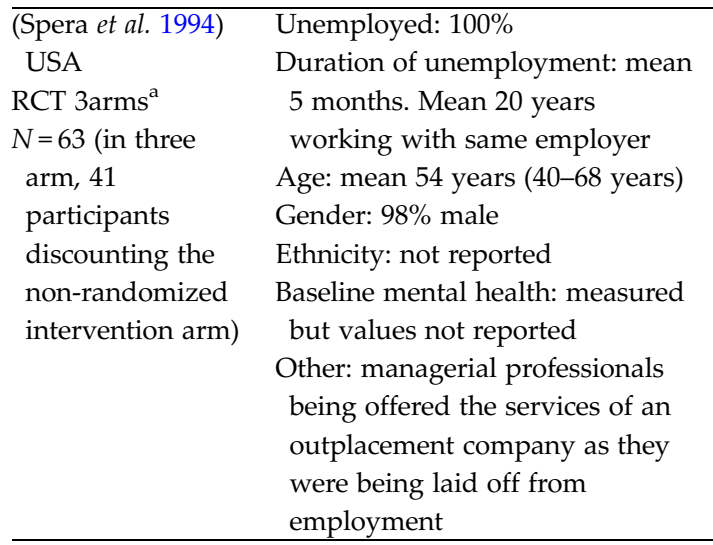

(Joseph, 1999;

Joseph \& Duration of unemployment: mean

Greenberg, 2001) unemployment duration 2.3

months, range (0-5.8 months)

Writing transition project

Daily, private, disclosive writing sessions

Professionals recruited from outplacement

Control writing: Daily, private,

for recording personal and deepest

firms

thoughts and feelings about

unemployment and how their lives both

personal and professional, had been

affected. Participants were encouraged to

explore their emotions deeply

Duration and frequency: 20 min daily for 5

days

RCT 2 arms

$N=76$

Age: mean 46.8 years (29-64 years)

Gender: 60\% male

Baseline mental health:

Intervention group mean CES-D

(s.D.) 12.38 (9.39) Control CES-D

16.68 (10.25)

Other: participants were described

as 'business workers'. Mean

years in last job 8.27 years $(0.17$ 30.58) years

(Hodzic et al.

2015a, b)

Spain

RCT 2 arms
Unemployed: $100 \%$

Duration of unemployment: mean

unemployment duration 16.9

months.
Guided imagery group intervention:

Components: six brief, 20 min session

Participants followed tape recorded

guided muscle relaxation followed by

guided imagery covering; emotional

experience of job loss and unemployment,

job search and job interview rehearsal,

positive self-regard and cognitive

reframing
Professionals recruited from outplacement firms

Emotional competences training: based on Kotsou et al. (2011)

Group work to identify and understand

emotions of the self and other, using

Unemployed from unemployment agencies Inclusion criteria. (a) being unemployed, (b) motivated about the intervention process,

(c) no prior knowledge about the disclosive writing sessions for recording plans for the day, and activities in job search

Duration and frequency: $20 \mathrm{~min}$ daily for 5 days

No intervention

Placebo imagery: Self-directed

visualization of job search plans and activities in the past and the future

6x20 min 'imagery sessions' following written instructions, thinking about their daily job search activities 


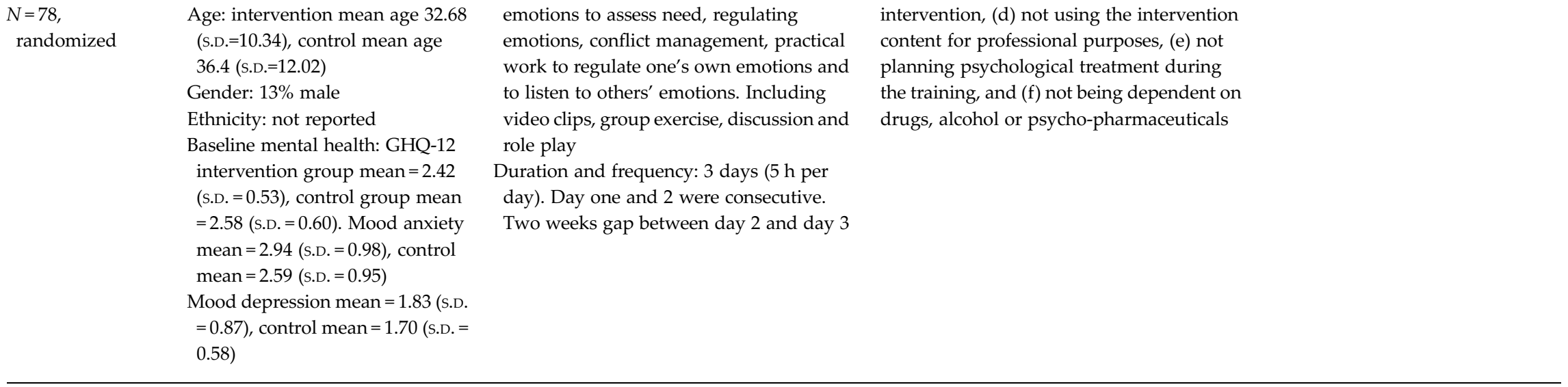

${ }^{a}$ Although Spera et al. (1994) had three arm study with $n=63$ participants we are using data from just two study arms $(n=41)$ the people in one of the groups (no writing) were not allocated during the randomization procedure (Spera et al. 1994). CES-D Centre of epidemiologic studies depression scale. 


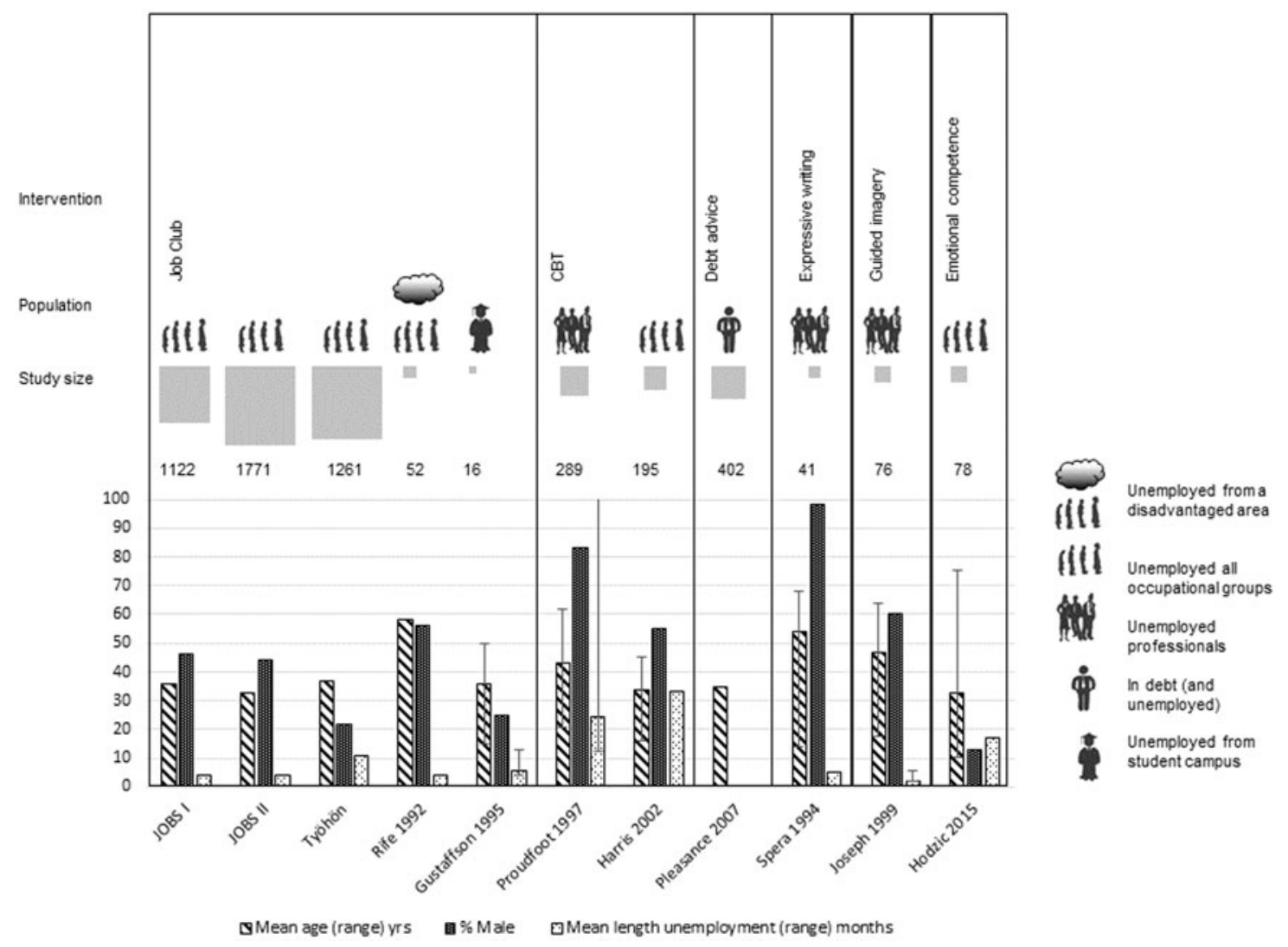

Fig. 2. Visualization of study characteristics. Ranges for age and length of unemployment were presented when data were available.

JOBS II evaluated a modified version of JOBS I and stratified participants at baseline according to their risk of depression (high or low). The authors reported a small improvement of depressive symptoms at 2 years for those who received the intervention (standardized linear regression coefficient $-0.06, p<0.05$ ) (see Table 2). As in JOBS I, stronger effects of approximately 0.2 S.D. improvements were seen in participants at high risk of depression (around $40 \%$ of the trial participants) (interaction: $F_{1,1331}=4.10, p=0.043$ ). There was no effect on the Composite Index of Depression Inventory (CIDI), a 9-point scale of likelihood of major depressive episode (MDE) (linear regression: -0.04 s.D. $p>0.05)$. However, using the more stringent criteria of probable ( $90 \%$ likely) to have a MDE (scores of 7 or 8 on CIDI) fewer people in the intervention group had probable MDE at 2 years compared to those in the control (odds ratio $0.61, p<0.05$ ). This intervention was also associated with improved employment at this time point (Vinokur et al. 1995b, 1996, 2000; Vinokur \& Schul, 1997). In the Finnish version of JOBS II, Työhön ('Let's get to work'), there were improved psychological symptoms (GHQ-12) at 6 months and improved depression symptoms at 6 months and 24 months, although, as described above for JOBS II, the actual size of the reduction in depressive symptoms was small. No analyses stratified by baseline depression risk were reported. In the Työhön study there was no effect on employment at 6 or 24 months (see Tables 2 and 3) (Vuori et al. 2002; Vuori \& Silvonen, 2005; Vuori \& Vinokur, 2005). Rife and colleagues assessed the effects of a similar intervention, more focussed on practical skills training, and reported that the people in the intervention group showed an improvement in depressive symptoms on the Geriatric Depression Scale at 3 months $(p<0.05)$ and more of this group were employed compared to the control group $(65 \%$ v. $26 \% p<0.01)$ (see Tables 2 and 3) (Rife, 1992; Rife \& Belcher, 1994). Gustafson's small $(n=16)$ trial found no effect of the 'job club' intervention on anxiety scores or employment (see Table 2), but was under-powered (Gustafson, 1995). The trials and subgroups where the greatest improvements were seen in employment were those in which participants experienced the greatest improvement in depression (Rife, 1992; Rife \& Belcher, 1994; Vinokur et al. 1995b).

\section{CBT interventions}

Two studies assessed the effect of group CBT on longterm unemployed individuals. The intervention content 


\begin{tabular}{|c|c|c|c|c|c|c|c|c|c|c|}
\hline \multirow[b]{2}{*}{ Intervention } & \multirow[b]{2}{*}{ Study name } & \multicolumn{4}{|l|}{ 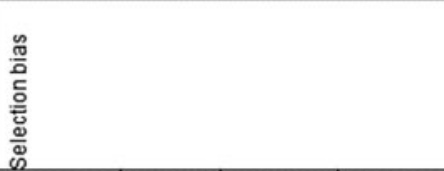 } & \multirow{2}{*}{ 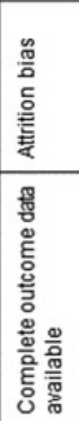 } & \multirow{2}{*}{ 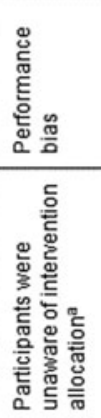 } & \multirow{2}{*}{ 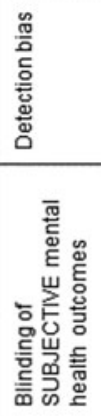 } & \multirow{2}{*}{ 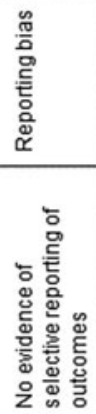 } & \multirow[b]{2}{*}{ 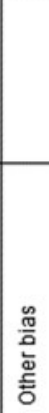 } \\
\hline & & 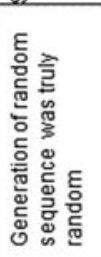 & 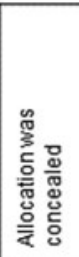 & 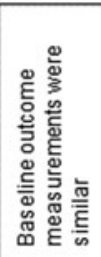 & 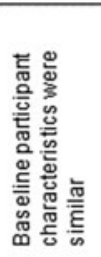 & & & & & \\
\hline \multirow[t]{5}{*}{ Job club } & JOBS I & $?$ & $?$ & $\checkmark$ & $\checkmark$ & $?$ & $x$ & $x$ & $?$ & $? 0$ \\
\hline & JOBS II & $\checkmark$ & $?$ & 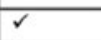 & 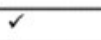 & $\checkmark$ & $x$ & $x$ & $x$ & $\checkmark$ \\
\hline & Työhön & $?$ & $?$ & 2 & 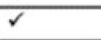 & $x$ & $x$ & $x$ & $?$ & 2 \\
\hline & Rife 1992 & $?$ & $?$ & 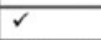 & 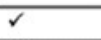 & $\checkmark$ & $\bar{x}$ & $x$ & $?$ & 2 \\
\hline & Gustaffson 1995 & $?$ & $?$ & 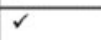 & 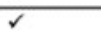 & $\checkmark$ & $\bar{x}$ & $x$ & $?$ & 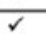 \\
\hline \multirow[t]{2}{*}{ CBT } & Proudfoot 1997 & 2 & $?$ & 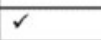 & 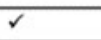 & $?$ & $x$ & $\bar{x}$ & $?$ & 2 \\
\hline & Harris 2002 & $?$ & $?$ & $x$ & $?$ & $x$ & $x$ & $x$ & $x$ & $\checkmark$ \\
\hline Debt Advice & Pleasance 2007 & $\checkmark$ & $\checkmark$ & $?$ & $?$ & $x$ & $\bar{x}$ & $\checkmark$ & $?$ & $x^{\circ}$ \\
\hline $\begin{array}{l}\text { Emotional competence } \\
\text { Training }\end{array}$ & Hodzic 2015 & $?$ & $?$ & $\checkmark$ & 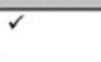 & $x$ & $x$ & $x$ & $?$ & $\checkmark$ \\
\hline Expressive writing & Spera 1994 & $?$ & $?$ & $\checkmark$ & $\checkmark$ & $?$ & $\bar{x}$ & $x$ & $?$ & $\checkmark$ \\
\hline Guided imagery & Joseph 1999 & $?$ & $?$ & $\checkmark$ & $\checkmark$ & $x$ & $x$ & $x$ & $\checkmark$ & $x^{\circ}$ \\
\hline
\end{tabular}

Fig. 3. Risk of bias. $\checkmark$ Domain was judged to be low risk of bias; $x$, domain was judged to be at high risk of bias; ?, it was

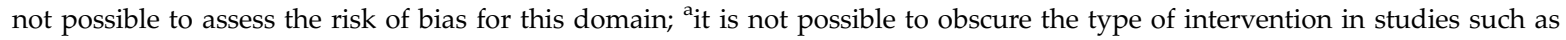
these as the participants are aware of the intervention they are receiving, therefore all studies are rated at high risk-of-bias; bemployment outcome was complex, dichotomised to working enough and not working enough however $14 \%$ of people did not meet these criteria and were not included in the outcome assessment; ${ }^{c}$ stopped early high drop out; ${ }^{\mathrm{d}}$ difference in baseline of people exposed to relaxation techniques. CBT, Cognitive behavioural therapy.

was similar in both trials, including cognitive restructuring, behaviour modification and homework assignments. However, Proudfoot et al. (1997) provided sessions of $3 \mathrm{~h}$ per week for 7 weeks $(21 \mathrm{~h})$ compared to Harris et al. (2002) who provided $11 \mathrm{~h}$ over 2 days (see Table 1 and Supplementary Appendix 3). Both studies used an active comparator arm [social support programme that included homework (Proudfoot et al. 1997) and a 2-day senior certificate in first aid (Harris et al. 2002)] to mimic the attention provided to participants in the intervention arm. The populations were quite different; Proudfoot et al. $(n=289)$ enrolled long-term $(>12$ months) unemployed professionals who were mostly $(83 \%)$ male, whereas Harris et al. $(n=195)$ targeted long-term unemployed individuals in disadvantaged areas who were of lower socioeconomic status and were 55\% male (see Table 1) (Harris et al. 2002; Proudfoot et al. 1997).

Proudfoot et al. reported that CBT improved mental health (GHQ-30) scores (difference in means: -1.44, 95\% $\mathrm{CI}-3.20$ to $0.32, p<0.05$ ) at 7 weeks but found no effect on the proportion of participants meeting thresholds for a psychiatric 'case' (defined as a score $>5$ on GHQ-30) in the intervention group (21\%) compared to the control group $(23 \%)(p=0.78$; see Table 2$)$. However, people receiving CBT were more likely to be employed at 7 weeks compared to those in the control group (34\% $v$. 13\%, $p=0.0006$; see Table 3) (Proudfoot et al. 1997). The second, smaller CBT trial of Harris et al. (2002) showed no effect on employment or the mental health indicators (Harris et al. 2002); if anything there was evidence of an adverse effect on measures of hopelessness (difference in means: $-2.04,95 \%$ CI 0.66 to 3.42 ) and optimism (difference in means: $-2.6,95 \%$ CI -4.10 to 1.10 ; see Table 2), although there were baseline differences between the study arms with higher levels of self-esteem (Table 2) and shorter durations of unemployment (Table 3) in the control compared to the intervention arm (Harris et al. 2002).

\section{Other interventions}

Four other interventions have been evaluated in single trials of 41-402 participants. Telephone debt advice to people $(n=402)$ who were in debt (recruited from unemployment offices) had no effect on measures of anxiety (Table 2) or on numerous measures of indebtedness (see Table 3) (Pleasence \& Balmer, 2007), but only 31\% of participants in the intervention group actually received debt advice and $10 \%$ of the control (no intervention) group independently sought debt advice (Pleasence \& Balmer, 2007). One study $(n=41)$ provided unemployed 
people with opportunities for expressive writing (20 $\mathrm{min}$ over 5 days where they could disclose effects of unemployment) compared to control writing (Spera et al. 1994). Expressive writing had no effect on symptoms of anxiety at 3 months (Table 2) but appeared to improve employment (Table 3) (Spera et al. 1994). Joseph and colleagues $(n=76)$ assessed the effects of guided imagery (20 min over six sessions) that allowed participants to visualize their success at finding and obtaining employment and also included relaxation techniques compared to control imagery (see Table 2) (Joseph, 1999; Joseph \& Greenberg, 2001). People who received guided imagery were more likely to be in employment at 7 weeks but there was no effect on depression (Tables 2 and 3) (Joseph, 1999; Joseph \& Greenberg, 2001). Finally, a trial $(n=75)$ of the provision of group emotional competency training for unemployed people compared to no intervention did not present an analysis of the effects emotional competency training on mental health but calculation of the difference in means and 95\% CIs showed no effect on (GHQ-12), nor on symptoms of depression, anxiety or stress (see Table 2) (Hodzic et al. 2015a).

\section{Discussion}

\section{Main findings}

There is consistent evidence from large RCTs in different settings, including three trials with more than 1000 participants, that intensive 1- to 2-week 'job club' interventions for unemployed people reduce the risk of depression. The most clinically relevant effects are seen among participants at increased risk of developing depression (around a quarter of participants); in this group, effect sizes of up to 0.5 s.D. improvements in depression scores were seen. Improvement in depression was seen for up to 2 years, although effects on employment were mixed. Larger effects on depression were seen in trials/subgroups with the greatest increases in employment.

The only other intervention investigated in more than one trial was group CBT. There was good evidence of a short-term (3 months) effect on depression symptoms and re-employment in the larger trial that delivered CBT over 7 weeks, though no effect on psychiatric 'caseness' (Proudfoot et al. 1997). The second showed no beneficial effects (Harris et al. 2002). Differences between these two trials may reflect differences in participants [professionals (Proudfoot et al. 1997) $v$. people from disadvantaged areas (Harris et al. 2002)] and timing/intensity of the intervention [21 h provided weekly over 7 weeks (Proudfoot et al. 1997) v. $11 \mathrm{~h}$ provided over 2 days (Harris et al. 2002)].

There is limited evidence for other interventions, but these were all evaluated in single trials with small sample sizes (Spera et al. 1994; Joseph \& Greenberg, 2001; Hodzic et al. 2015a) or limited uptake of the intervention (Pleasence \& Balmer, 2007).

Risk of bias was a problem for many of the studies with a third of the items rendered not assessable because the items were not reported. Taking into account the high risk of bias of the studies we have to interpret the strength of the evidence with some caution. Studies varied in the quality of reporting important details of interventions. In four a manual was used (Caplan et al. 1989; Vinokur et al. 1995b; Harris et al. 2002; Vuori et al. 2002) and three included an assessment of fidelity to treatment (Caplan et al. 1989; Vinokur et al. 1995b; Vuori et al. 2002). Detailed descriptions of interventions and assessments made to assess fidelity to treatment should be described in future studies (Craig et al. 2008).

Evidence of improvement in depressive symptoms in intervention group participants coincided in some studies with higher levels of re-employment (JOBS II high-risk group and Proudfoot et al.) (Vinokur et al. 1995b; Proudfoot et al. 1997, 1999; Vinokur et al. 2000); however, in some studies this was not the case (JOBS I and Työhön) (Vinokur et al. 1991b; Price et al. 1992; Vuori et al. 2002; Vuori \& Silvonen, 2005). Some studies looked for aspects of the intervention that might contribute to the change in outcome (mediating effects). There was some evidence in JOBS II that reduced depressive symptoms were associated with reduction of financial strain and reemployment (Vinokur \& Schul, 1997). Job search preparedness (selfefficacy and inoculation against setbacks) reduced depressive symptoms and improved employment in JOBS I and Työhön but the authors do not present an analysis on effects of employment on mental health for JOBS I (Vanryn \& Vinokur, 1992; Vuori \& Vinokur, 2005). Työhön authors did identify a link between reduced financial strain and reduction in depressive symptoms (Vuori \& Vinokur, 2005).

\section{Strengths and limitations}

To the best of our knowledge this is the first comprehensive review of RCT evidence of interventions targeted at alleviating the impact on mental health of unemployment and debt in general population samples. Two reviews with a narrower focus solely on 'job search' interventions, which included evidence from non-randomized studies, reported that 'job search' interventions reduced depression and anxiety and improved employment (Audhoe et al. 2010; Liu et al. 2014). A strong evidence base in this area is important to inform policy responses to future recessions as these are associated with rises in unemployment, debt, depression, and suicidal behaviour. Our review facilitates an overview of the types of 
Table 2. Mental health outcomes by Intervention type

\begin{tabular}{|c|c|c|c|c|c|c|c|c|c|c|c|}
\hline \multirow{2}{*}{\multicolumn{2}{|c|}{ Intervention type Outcome }} & \multirow[b]{2}{*}{ Outcome scale } & \multirow[b]{2}{*}{ Study } & \multirow[b]{2}{*}{$n$} & \multirow{2}{*}{$\begin{array}{l}\text { Time point } \\
\text { (sample) }\end{array}$} & \multicolumn{2}{|l|}{ Intervention } & \multicolumn{2}{|l|}{ Control } & \multirow{2}{*}{$\begin{array}{l}\text { Published } \\
\text { analysis by } \\
\text { trial authors }\end{array}$} & \multirow{2}{*}{$\begin{array}{l}\text { Calculation of difference } \\
\text { in means, or risk } \\
\text { difference, } \\
\text { using available } \\
\text { published summary } \\
\text { data from studies }{ }^{\mathrm{a}, \mathrm{b}}\end{array}$} \\
\hline & & & & & & Mean (S.D.) & $n$ & Mean (S.D.) & $n$ & & \\
\hline \multirow[t]{18}{*}{ Job club } & Anxiety & $\begin{array}{l}\text { Subscale of } \\
\text { HSCL-90 }\end{array}$ & JOBS I & 630 & 6 weeks (all) & $1.87(-)$ & - & $1.88(-)$ & - & $\begin{aligned} \mathrm{ES} & =-0.03 \\
t & =0.36(630 \mathrm{df}) \\
p & =0.718\end{aligned}$ & $\begin{array}{l}\text { MD }-0.01 \text { (not } \\
\text { calculable) }\end{array}$ \\
\hline & & & & 623 & 4 months (all) & $1.89(-)$ & - & $1.86(-)$ & - & $\begin{aligned} \mathrm{ES} & =0.04, t=0.45(623 \mathrm{df}) \\
p & =0.652\end{aligned}$ & $\begin{array}{l}\text { MD }-0.03 \text { (not } \\
\text { calculable) }\end{array}$ \\
\hline & & STAI State & Gustafson 1995 & 16 & 6 weeks & $43.7(14.9)$ & 8 & $38.0(6.9)$ & 8 & $\chi^{2} p>0.05$ & $\begin{array}{l}\text { MD } 5.70 \\
(-5.68 \text { to } 17.08)\end{array}$ \\
\hline & & STAI Trait & & 16 & 6 weeks & $41.7(10.7)$ & 8 & $44.6(7.3)$ & 8 & $\chi^{2} p>0.05$ & $\begin{array}{l}\mathrm{MD}-2.90(-11.88 \text { to } \\
6.08)\end{array}$ \\
\hline & Depression & HSCL-90 & JOBS I & 630 & 6 weeks (all) & $1.84(-)$ & - & $1.91(-)$ & - & $\begin{aligned} \mathrm{ES} & =-0.09 \\
t & =-1.12(630 \mathrm{df}) \\
p & =0.263 \mathrm{~ns}\end{aligned}$ & MD - 0.07 (not estimable) \\
\hline & & & & 522 & 6 weeks (low) ${ }^{c}$ & $1.67(0.50)$ & 340 & $1.60(0.51)$ & 182 & $\begin{array}{l}\text { Interaction } \\
\qquad F=6.07, p=0.01^{\mathrm{d}}\end{array}$ & $\begin{array}{l}\text { MD } 0.07 \\
(-0.02 \text { to } 0.16)\end{array}$ \\
\hline & & & & 179 & $\begin{array}{l}6 \text { weeks } \\
(\text { high })^{c}\end{array}$ & $2.21(0.73)$ & 117 & $2.47(0.70)$ & 62 & & $\begin{array}{l}\mathrm{MD}-0.26 \\
(-0.48 \text { to }-0.04)\end{array}$ \\
\hline & & & & 623 & 4 months (all) & $1.84(-)$ & - & $1.92(-)$ & - & $\begin{array}{l}\mathrm{ES}=-0.11, t=-1.30 \\
(623 \mathrm{df}) \\
p=0.194 \mathrm{~ns}\end{array}$ & MD -0.08 (not estimable) \\
\hline & & & & 695 & 4 months (all) & $1.72(0.63)$ & 465 & $1.84(0.69)$ & 230 & $t$ test $\mathrm{ns}$ & $\begin{array}{l}\mathrm{MD}-0.13 \\
\quad(-0.24 \text { to }-0.02)\end{array}$ \\
\hline & & & & 511 & 4 months (low) ${ }^{c}$ & $1.59(0.55)$ & 343 & $1.63(0.52)$ & 168 & $\begin{array}{l}\text { Interaction } F=12.14, \\
p=0.001^{\mathrm{d}}\end{array}$ & $\begin{array}{l}\mathrm{MD}-0.04 \\
\quad(-0.14 \text { to } 0.06)\end{array}$ \\
\hline & & & & 184 & 4 months $\left(\right.$ high) ${ }^{\mathrm{c}}$ & $2.08(0.72)$ & 122 & $2.44(0.78)$ & 62 & & $\begin{array}{l}\mathrm{MD}-0.36(-0.59 \text { to } \\
-0.13)\end{array}$ \\
\hline & & & & 456 & 28 months $(\text { low })^{c}$ & $1.55(0.53)$ & 305 & $1.61(0.56)$ & 151 & $\begin{array}{c}\text { Interaction } F=6.05, \\
p=0.01^{\mathrm{d}}\end{array}$ & $\begin{array}{l}\mathrm{MD}-0.06 \\
(-0.17 \text { to } 0.05)\end{array}$ \\
\hline & & & & 157 & 28 months $(\text { high })^{c}$ & $1.95(0.73)$ & 103 & $2.20(0.77)$ & 52 & & $\mathrm{MD}-0.25$ ( -0.50 to 0.00$)$ \\
\hline & & HSCL-90 & JOBS II & 742 & 2-6 months (low) & - & - & - & - & - & - \\
\hline & & & & 470 & $\begin{array}{l}\text { 2-6 months } \\
\text { (high) }\end{array}$ & - & - & - & - & $\begin{array}{l}F_{1,1331}=4.10 p=0.043 \\
\text { difference }=-0.2 \text { s.D. at } \\
2 \text { months Difference }= \\
-0.22 \text { s.D. at } 6 \text { months }{ }^{\text {e }} \text { - }\end{array}$ & - \\
\hline & & & & 578 & 24 months (all) & - & - & - & - & Beta $\mathrm{LR}=-0.06, p<0.05$ & - \\
\hline & & CIDI MDE ${ }^{f}$ & & 578 & 24 months (all) & - & - & - & - & Beta $\mathrm{LR}=-0.04, p>0.05$ & - \\
\hline & & $\begin{array}{l}\text { CIDI Probable } \\
\text { MDE }^{\mathrm{f}}\end{array}$ & & 578 & 24 months (all) & - & - & - & - & $\begin{array}{c}\text { Beta } \log \mathrm{R}=-0.49 \\
p<0.05(\mathrm{OR}=0.612)\end{array}$ & - \\
\hline
\end{tabular}


Table 2 (cont.)

\begin{tabular}{|c|c|c|c|c|c|c|c|c|c|c|c|}
\hline & & \multirow[b]{2}{*}{ Outcome scale } & \multirow[b]{2}{*}{ Study } & \multirow[b]{2}{*}{$n$} & \multirow{2}{*}{$\begin{array}{l}\text { Time point } \\
\text { (sample) }\end{array}$} & \multicolumn{2}{|l|}{ Intervention } & \multicolumn{2}{|l|}{ Control } & \multirow{2}{*}{$\begin{array}{l}\text { Published } \\
\text { analysis by } \\
\text { trial authors }\end{array}$} & \multirow{2}{*}{$\begin{array}{l}\text { Calculation of difference } \\
\text { in means, or risk } \\
\text { difference, } \\
\text { using available } \\
\text { published summary } \\
\text { data from studies }{ }^{\mathrm{a}, \mathrm{b}}\end{array}$} \\
\hline \multicolumn{2}{|c|}{ Intervention type Outcome } & & & & & Mean (S.D.) & $n$ & Mean (S.D.) & $n$ & & \\
\hline & & GDS & Rife 1992 & 52 & 12 weeks & $5.03(-)$ & 26 & $7.07(-)$ & 26 & $\begin{array}{l}\text { MW U 188.5, Z }=-2.76 \\
p<0.05\end{array}$ & $\begin{array}{l}\text { MD }-2.0 \\
\text { (not estimable) }\end{array}$ \\
\hline & & HSCL90 & Työhön & 1049 & 6 months & - & - & - & - & $\begin{array}{l}\text { SLRC } \\
(\text { Beta })=-0.04 \mathrm{~ns}\end{array}$ & \\
\hline & & & & 1261 & 24 months & - & - & - & - & $\begin{array}{l}\text { SLRC } \\
(\text { Beta })=-0.06, p<0.05\end{array}$ & \\
\hline & $\begin{array}{l}\text { Psychological } \\
\text { symptoms }\end{array}$ & GHQ-12 & Työhön & 1049 & 6 months & - & - & - & - & $\begin{array}{l}\text { SLRC }(\text { Beta })=-0.06 \\
p<0.05\end{array}$ & \\
\hline & & & & 952 & 24 months & - & - & - & - & $\begin{array}{l}\text { SLRC }(\text { Beta })=-0.06 \\
p<0.05\end{array}$ & \\
\hline \multirow[t]{6}{*}{ CBT } & $\begin{array}{l}\text { Psychiatric } \\
\text { caseness }\end{array}$ & $\begin{array}{l}\text { Score }>5 \text { on } \\
\text { GHQ-30 }\end{array}$ & Proudfoot 1997 & 209 & 7 weeks & - & - & - & - & $\begin{array}{l}21 \% \text { CBT } 23 \% \text { control } \\
t \text { test, } p=0.78\end{array}$ & RD-0.01 (-0.12 to 0.09$)$ \\
\hline & $\begin{array}{l}\text { Psychiatric } \\
\text { symptoms }\end{array}$ & GHQ-30 & & 209 & 7 weeks & $3.72(5.81)$ & 112 & $5.16(7.01)$ & 97 & $F=3.91, p<0.05^{g}$ & MD -1.44 ( -3.20 to 0.32$)$ \\
\hline & & & & 183 & 3 months & $4.92(7.21)$ & 94 & $6.58(8.14)$ & 89 & $F=3.85, p<0.05^{g}$ & $\mathrm{MD}-1.66(-3.89$ to 0.57$)$ \\
\hline & & SF-36 MCS & Harris 2002 & 195 & 3-4 months & $44.14(12.19)$ & 57 & $46.31(12.78)$ & 43 & $t$ test $\mathrm{ns}^{\mathrm{h}}$ & $\mathrm{MD}-2.17$ ( -7.13 to 2.79$)$ \\
\hline & Mood & BHS & Harris 2002 & & $3-4$ months & $5.11(4.27)$ & 57 & $3.07(2.73)$ & 43 & $F_{1,97}=7.26, p=0.01^{\mathrm{g}}$ & MD 2.04 (0.66 to 3.42$)$ \\
\hline & & LSS Opt & & & 3-4 months & $13.54(4.09)$ & 57 & $16.14(3.54)$ & 43 & $F_{1,97}=7.29, p=0.01^{g}$ & $\begin{array}{l}\mathrm{MD}-2.60(-4.10 \text { to } \\
-1.10)\end{array}$ \\
\hline Debt advice & Anxiety & STAI-6 & Pleasence 2007 & $402^{\mathrm{i}}$ & $0-5$ months & - & - & - & - & $\begin{array}{l}\text { MVM ES -2.43, S.E. }=2.73 \\
\text { ns }\end{array}$ & \\
\hline \multicolumn{12}{|c|}{ Emotional competence training } \\
\hline & Mental health & GHQ-12 & Hodzic 2015 & 75 & 1 months & $2.18(0.59)$ & 41 & $2.48(0.60)$ & 34 & & $\mathrm{MD}-0.30$ ( -0.57 to 0.03$)$ \\
\hline & & & & & 6 months & $2.20(0.53)$ & 38 & $2.38(0.53)$ & 26 & & MD $0.18(-0.44$ to 0.08$)$ \\
\hline & Stress & PSSS & & 75 & 1 months & $2.73(0.66)$ & 41 & $2.69(0.66)$ & 34 & & MD $0.04(-0.26$ to 0.34$)$ \\
\hline & & & & 64 & 6 months & $2.61(0.60)$ & 38 & $2.69(0.56)$ & 26 & & MD -0.08 ( -0.37 to 0.21$)$ \\
\hline & Anxiety & POMS & & 75 & 1 months & $2.63(0.92)$ & 41 & $2.73(0.98)$ & 34 & & $\mathrm{MD}-0.10$ (0.53 to 0.33$)$ \\
\hline
\end{tabular}




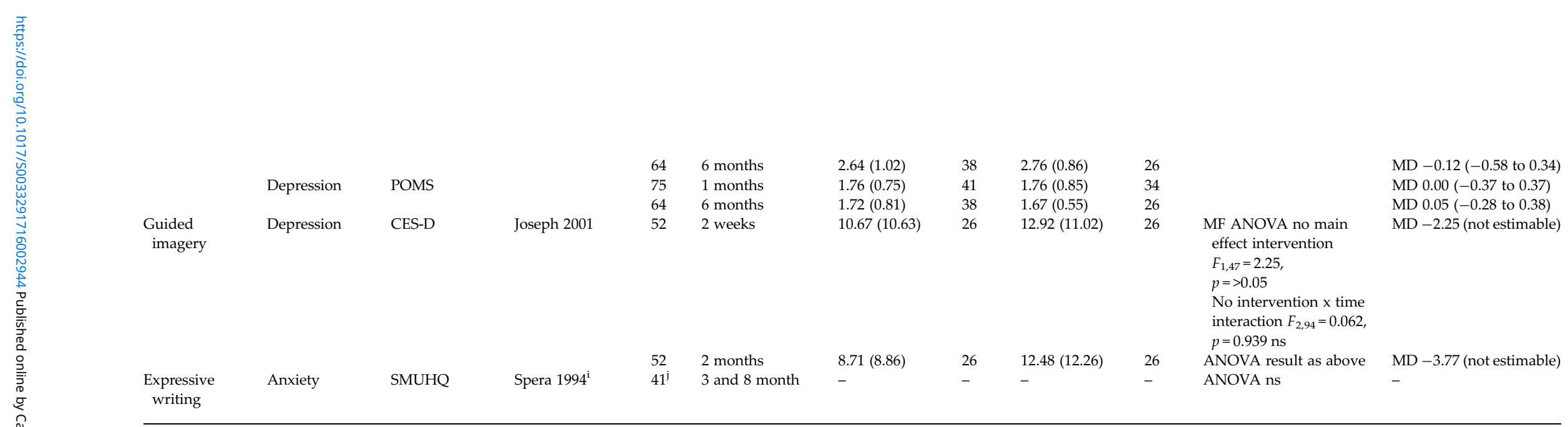

BHS, Beck Hopelessness Scale; CES-D, Centre of Epidemiologic Studies Depression Scale; ES, Effect size; GDS, Geriatric Depression Scale; GHQ-12, General Health Questionnaire 12 items. Self-report measure of psychological morbidity (Goldberg et al. 1997); GHQ-30, General Health Questionnaire 30 Item. Self-report measure of psychological morbidity; HSCL-90, Hopkins Symptom Checklist 90 Subscale - 11 items adapted for use in Finland (Vuori et al. 2002). The measure of depressive symptoms was a 10-item Finnish scale (Salokangas et al. 1994) based on the Hopkins Checklist (Derogatis et al. 1974) Cronbach's $\alpha$ coefficients were 0.92 at T1 and 0.92 at T4; Log R, Logistic regression; LR, Linear Regressions; LSS-Opt, Life satisfaction scale subscale optimism; MD, difference in means; MF ANOVA, multifactorial ANOVA; MVM, multivariate model, Pleasence \& Balmer (2007). The authors state 'We fitted a multivariate model fitting STAI-6 and EQ-5D scores simultaneously as normal response variables' The effect sizes they report are changes from baseline to follow-up at 20 weeks; MW-U, Mann-Whitney $U$; ns, not reaching the statistical significance of a $p$ value $\leqslant 0.05$; OR, odds ratio; POM, Profile of Mood States Questionnaire; PSS, Perceived Stress Scale; RD, risk difference; SF-36, Short-Form-36 Health Survey Questionnaire (Ware et al. 1994); SLRC, Standardized linear regression coefficient; For the Työhön study the S.D. for the HSCL-90 were reported as 6 for the intervention or 6.5 for the control. Therefore a change in 0.06 of a s.D. represents a change in score of 0.36 of a point on the HSCL-90 scale). For the JOBS II study no S.D. is provided for the HSCL-90; SMUHQ, Southern Methodists University Health Questionnaire (Watson \& Pennebaker, 1989); STAI, Stait Trait Anxiety Scale (reduction in score= benefit range 20-80 score of $>42=$ case). Gustafson 1995; 6 week data (Gustafson, 1995): Harris 2002; 3-4 month data (Harris et al. 2002): Hodzic 2015; 1 month and 6 month data (Hodzic et al. 2015a): JOBS I; 6 week, 4 month data (Vinokur et al. 1991a), 28 month data (Vinokur et al. 1991b), low risk and high risk data all time points (Price et al. 1992): JOBS II; 2 month and 6 month data (Vinokur et al. 1995b), 2 year data (Vinokur et al. 2000): Joseph 2001; 2 week and 2 month data (Joseph, 1999, Joseph \& Greenberg, 2001): Rife 1992; 12 week data (Rife, 1992): Työhön; 6 month data (Vuori et al. 2002); 24 month data (Vuori \& Silvonen, 2005): Pleasance 2007; 0-5 month (Pleasence \& Balmer, 2007): Proudfoot 1997; 7 week data (Proudfoot et al. 1999, Proudfoot et al. 1997): Spera 1994 (Spera et al. 1994).

${ }^{a}$ Risk difference calculated using methods described in Deeks \& Higgins (2010) Statistical algorithms in Review Manager 5.2 (Deeks \& Higgins, 2010 ).

${ }^{\mathrm{b}}$ Mean difference calculated using methods described in Salanti (2013) Statistical algorithms for the Calculator in Review Manager 5.2 (Salanti, 2013 ).

${ }^{c}$ Data from Price et al. (1992). Participants were at high or low risk of depression. NB People scoring $\geqslant 3$ on pre-test depression were excluded from the analysis.

${ }^{\mathrm{d}}$ Two-way ANCOVA (analysis of covariance) baseline depression and hours of employment as covariates and stratified by predicted risk of depression score (75\% low risk; $25 \%$ high risk) (Price et al. 1992)

${ }^{\mathrm{e}}$ Generalized linear model analysis of variance (ANOVA) $4.10=F$ of interaction of risk (high or low) and condition (intervention or control) (Vinokur et al. 1995b).

${ }^{\mathrm{f}} \mathrm{CIDI}$ (Composite Index of Depression Inventory). Defines the occurrence of major depressive episode (MDE). A less stringent definition of 'probable' MDE was defined by dichotomizing a score of $0-6=0$ or no diagnosis whilst $7-8=1$ or probable diagnosis MDE.

${ }^{g}$ ANCOVA (analysis of covariance) with pre-test scores as covariates.

${ }^{\mathrm{h}}$ Harris $e t$ al. do not present the $p$ values for the $t$ tests for SF-36 MCS. The $t$ test is for baseline to follow-up within groups, i.e. not comparing groups. The authors report a $\chi^{2}$ analysis to test for differences between groups but these data were not presented. They also prepare an ANCOVA using baseline values as covariates - and do not present these data.

${ }^{i}$ Only $31 \%$ of the intervention group received debt advice. $10 \%$ of the control group sought and obtained debt advice.

${ }^{j}$ Although the Spera et al. (1994) study had three arms $(n=63)$ only two of the arms (Writing and No writing $\left.n=41\right)$ were allocated at random. While we are reporting only from these two study arms the ANOVA analyses include all three arms. 
Table 3. Employment, debt and debt awareness outcomes by intervention type

\begin{tabular}{|c|c|c|c|c|c|c|c|c|}
\hline Intervention type & Study & Outcome & Time point & $n$ & $\begin{array}{l}\text { Intervention } \\
\%\end{array}$ & $\begin{array}{l}\text { Control } \\
\%\end{array}$ & $\begin{array}{l}\text { Statistical evidence for } \\
\text { differences }\end{array}$ & $\begin{array}{l}\text { Calculation of difference in means, or } \\
\text { risk difference, using available } \\
\text { published summary data from studies }\end{array}$ \\
\hline \multirow[t]{12}{*}{ Job club } & \multirow[t]{3}{*}{ JOBS I } & \multirow[t]{3}{*}{ Employment $^{c}$} & 6 weeks & 563 & 33 & 26 & $t$ test $\mathrm{ns}^{\mathrm{d}}$ & RD $0.07(0.00-0.14)$ \\
\hline & & & 4 months & 499 & 60 & 51 & $t$ test $\mathrm{ns}^{\mathrm{d}}$ & RD 0.08 ( -0.00 to 0.16$)$ \\
\hline & & & 28 months & & 71.2 & 68.3 & MANOVA $F=1.25 \mathrm{~ns}^{\mathrm{e}}$ & Not estimable \\
\hline & Gustafson 1995 & Employment & 6 weeks & 16 & 63 & 50 & $\chi^{2} p>0.05$ & $\mathrm{RD}-0.13$ ( -0.61 to 0.36$)$ \\
\hline & \multirow[t]{5}{*}{ JOBS II } & \multirow[t]{5}{*}{ Employment $^{\mathrm{c}}$} & 2 months & & 34 & 27 & Wald's $\chi^{2}=4.44, p>0.05$ & RD 0.07 (not estimable) \\
\hline & & & 2 months & & 35 & 29 & Wald's $\chi^{2}=5.79, p>0.05$ & RD 0.06 (not estimable) \\
\hline & & & 6 months & & 63 & 67 & Wald's $\chi^{2}=4.13, p<0.05$ & RD 0.04 (not estimable) \\
\hline & & & 6 months & & 62 & 54 & Wald's $\chi^{2}=4.55, p<0.05$ & RD 0.08 (not estimable) \\
\hline & & & 24 months & - & - & - & $\begin{array}{c}\mathrm{BLRC}=0.44, \mathrm{OR}=1.55 \\
p<0.001\end{array}$ & Not estimable \\
\hline & Rife 1992 & Employment & 12 weeks & 52 & 65 & 26 & $\chi^{2}(1)=7.73, p<0.01$ & RD 0.38 (0.13-0.63) \\
\hline & \multirow{2}{*}{ Työhön } & \multirow{2}{*}{ Employment } & 6 months & 1261 & 34 & 31.9 & ns & RD $0.02(-0.04-0.08)$ \\
\hline & & & 24 months & 1112 & 54.1 & 49.5 & $\chi^{2}=2.41 \mathrm{~ns}$ & RD 0.05 ( -0.02 to 0.11$)$ \\
\hline \multirow[t]{3}{*}{ CBT } & \multirow[t]{2}{*}{ Proudfoot 1997} & Employment & 4 months & 209 & 34 & 13 & $\chi^{2} p=0.0006$ & RD 0.21 (0.09 to 0.32$)$ \\
\hline & & FT PT temp & 4 months & 209 & 49 & 28 & $\chi^{2} p=0.0016$ & RD $0.21(0.08-0.34)$ \\
\hline & Harris 2002 & Employment activity $^{\mathrm{f}}$ & 3-4 months & 100 & - & - & $\chi^{2}=0.27, p=0.35$ & Not estimable \\
\hline \multirow[t]{2}{*}{ Guided imagery } & \multirow[t]{2}{*}{ Joseph 2001} & \multirow[t]{2}{*}{ Employment } & 2 months & 52 & 62 & 11 & $\chi^{2}=14.02, p<0.001$ & RD $0.50(0.28-0.72)$ \\
\hline & & & 4 months & 124 & 69 & 38 & $X^{2}=5.79, p<0.001$ & RD $0.31(0.05-0.57)$ \\
\hline \multirow[t]{3}{*}{$\begin{array}{l}\text { Expressive } \\
\text { writing }\end{array}$} & \multirow[t]{3}{*}{ Spera $1994^{g}$} & \multirow[t]{2}{*}{ Employment } & 3 months & $41^{\mathrm{g}}$ & 25 & 0 & $\begin{array}{l}t_{50}=2.10, p=0.04 \\
\text { ANOVA } F_{2,59}=3.72, \\
p=0.03^{\mathrm{f}}\end{array}$ & RD $0.25(0.05-0.45)$ \\
\hline & & & 8 months & $41^{\mathrm{g}}$ & 52.6 & 23.8 & - & RD 0.29 ( -0.00 to 0.58$)$ \\
\hline & & FT; PT and contract & 8 months & $41^{g}$ & 68.4 & 47.6 & $\begin{array}{l}\text { ANOVA } F_{2,59}=3.72, \\
p=0.03^{\mathrm{h}}\end{array}$ & RD 0.22 ( -0.07 to 0.52$)$ \\
\hline \multirow{2}{*}{$\begin{array}{l}\text { Emotional } \\
\text { competence } \\
\text { training }\end{array}$} & \multirow[t]{2}{*}{ Hodzic 2015} & \multirow[t]{2}{*}{ Employment } & 6 months & 63 & $21.2 \%(7)$ & $10 \%(3)$ & $\chi^{2}=1.48, p=0.22$ & RD 0.11 ( -0.06 to 0.29$)$ \\
\hline & & & 12 months & 63 & $36.4 \%(12)$ & $10 \%(3)$ & $\chi^{2}=6.02, p=0.01$ & RD $0.26(0.07-0.46)$ \\
\hline \multirow[t]{2}{*}{ Debt advice } & \multirow[t]{2}{*}{ Pleasance 2007} & Facing a debt problem & $0-5$ months & 234 & 35 & 37 & $\chi^{2} 2=0.22, p=0.64$ & RD $0.92(0.65-1.30)$ \\
\hline & & $\begin{array}{l}\text { Perceived changes in } \\
\text { financial circumstances } \\
\text { 'better' }\end{array}$ & 5 months & 234 & 42 & 30.1 & $\begin{array}{l}\text { ORM estimate } \\
\text { intervention }=0.23, \\
\text { S.E. }=0.24, p=0.34^{\mathrm{i}}\end{array}$ & RD 0.12 (not estimable) \\
\hline
\end{tabular}




\begin{tabular}{|c|c|c|c|c|c|c|}
\hline $\begin{array}{l}\text { Perceived changes in } \\
\text { financial circumstances } \\
\text { 'the same' }\end{array}$ & 5 months & 234 & 17.6 & 24.8 & $\chi^{2}=5.92, p=0.015$ & RD 0.07 (not estimable) \\
\hline See a future without debt & 5 months & 234 & - & - & $\begin{array}{l}\text { BLRA estimate } \\
\text { intervention }=0.32, \\
\text { S.E. }=0.33 \mathrm{~ns}\end{array}$ & \\
\hline \multirow[t]{2}{*}{$\begin{array}{l}\text { Knowledge of debt } \\
\text { problems }\end{array}$} & 5 months & 234 & - & - & $\begin{array}{l}\text { NRM intervention }=0.56 \text {, } \\
\text { S.E. }=0.30, \text { Wald test } \chi^{2}= \\
3.47, p=0.06\end{array}$ & \\
\hline & & & $\begin{array}{l}\text { Intervention } \\
\text { mean }\end{array}$ & $\begin{array}{l}\text { Control } \\
\text { mean }\end{array}$ & & \\
\hline Number of debts & 5 months & 234 & 2.29 & 2.16 & $\begin{array}{l}\text { Poisson model }-0.03 \text {, } \\
\text { S.E. }=0.10 \mathrm{~ns}\end{array}$ & MD 0.13 (not estimable) \\
\hline
\end{tabular}

BLRA, Binary logistic regression analysis; BLRC, binary logistic regression coefficient; Contract, contract employment; FT, full time; NRM, normal response model; MD, difference in means; OR, odds ratio; PT, part time; RD, risk difference; Temp, temporary. Gustafson 1995; 6 week data (Gustafson, 1995): Harris 2002; 3 to 4 month data (Harris et al. 2002); Hodzic 2015; 6 month and 1 year data (Hodzic et al. 2015b): JOBS I; 6 week, 4 month data (Vinokur et al. 1991a), 28 month data (Vinokur et al. 1991b): JOBS II 2 month and 6 month data

(Vinokur et al. 1995b); 2 year data (Vinokur et al. 2000): Joseph 2001; 2 week and 2 month data (Joseph, 1999; Joseph \& Greenberg, 2001): Rife 1992; 12 week data (Rife, 1992): Työhön 6 month data (Vuori et al. 2002); 24 month data (Vuori \& Silvonen, 2005): Pleasence 2007; 0 to 5 month data (Pleasence \& Balmer, 2007): Proudfoot 1997; 4 month (Proudfoot et al. 1997); Spera, 1994; (Spera et al. 1994).

${ }^{a}$ Risk difference calculated using methods described in Deeks \& Higgins (2010) Statistical algorithms in Review Manager 5.2 (Deeks \& Higgins, 2010 ).

${ }^{\mathrm{b}}$ Mean difference calculated using (Salanti, 2013). Statistical algorithms for the Calculator in Review Manager 5.2.

${ }^{\mathrm{c}}$ Employed $>20 \mathrm{~h}$ per week and considered to be 'working enough'.

d Employment in JOBS I was defined as working $20 \mathrm{~h}$ per week or more PLUS working as many hours as they needed.

${ }^{\mathrm{e}}$ Multivariate analysis of variance (MANOVA).

${ }^{\mathrm{f}}$ Some employment related activity, i.e. temporary, part-time, unpaid, paid, casual or full-time employment or enrolment in part or full-time study.

${ }^{g}$ Although the Spera et al. (1994) study had three arms $(n=63)$ only two of the arms (Writing and No writing $\left.n=41\right)$ were allocated at random. While we are reporting only from these two study arms for the ANOVA analyses include all three arms. For this analysis only data from 40 participants were available.

${ }^{\mathrm{h}}$ ANOVA across all three intervention arms shows there are significant variation in number employed $\left(F_{2,59}=3.72 p=0.03\right)$.

${ }^{i}$ ORM Ordinal regression model was fitted across the five categories (much better, better, the same, worse, and much worse) and there were no differences between categories by intervention type. When the data were looked at for each category, only one was significant, the people who had the intervention were more likely to score their perception of debt as 'better' Wald text $\chi^{2}=5.92, p=0.015$. 
interventions considered to date, providing pointers to what works best to inform future research in this field.

The main limitation is the relatively sparse literature in this field. The only intervention evaluated in large trials in different settings was the 'job club' intervention and results for these trials are not presented in such a way as to enable meta-analysis. Thus identifying what works for whom and when was not possible from this data set. There is some evidence from a systematic review that included non-randomized studies that job-search interventions only appeared to improve employment if they included components that developed skills and enhanced motivation, although mediating effects on mental health were not investigated (Liu et al. 2014). In JOBS II there was some evidence that the intervention had the greatest effects on mental health among those individuals with low levels of mastery (a composite measure based on self-esteem, self-efficacy and locus of control measures) at baseline, but such effects have not been investigated systematically (Vinokur et al. 2000). Suicide (incidence 11.4/1 00000 ) and attempted suicide (4/1000), possibly the most severe effect of economic hardship, are thankfully relatively rare (WHO, 2014, 2016); reported trials are underpowered to detect any effect on these indicators and were not evaluated in the studies we reviewed. Our focus was on trials evaluating mental health, the key risk factor for suicide and we assumed that interventions having an impact on mental health will in turn influence suicide attempts and suicide. The studies we identified used a range of outcome measures (GHQ-12, GHQ-30, SF-36, GDS, PSSS, Beck Hopelessness scale, POMS, CIDI, CES-D HSCL-90, STAI) designed to measure different aspects of mental health and ranging from disorder specific scales (e.g. CES-D) to screens for common mental disorder (GHQ-12). We excluded 20 reports of RCTs because they did not report any measures for mental health and we would recommend that any future trialists investigating interventions for debt and unemployment collect and publish such outcomes.

A priori we decided not to review the literature on specific groups, e.g. people with severe mental illness and single mothers, although some of the included trials did focus on population subgroups [e.g. unemployed professionals (Proudfoot et al. 1997), long-term unemployed living in deprived areas (Harris et al. 2002)]. Literature in this area is rather old and largely focused on the unemployed/job loss. The one trial of debt advice had to be stopped early because of high levels of loss to follow-up (Pleasence \& Balmer, 2007; Pleasence, 2008).

\section{Findings in the context of the wider literature}

The focus of our review has been on the relatively few RCTs in this field. Conducting trials in the context of economic recession is challenging as the rapid rises in job loss and debt require timely policy responses. Timescales for obtaining research funding to conduct RCTs, and time delays in obtaining research ethics approval (Salman et al. 2014), means that by the time a trial is funded the most acute period of economic difficulty may have passed. Three previous systematic reviews have all remarked upon the absence of evidence of health benefits for public health interventions for people on low income. One found 10 RCTs on income supplementation by searching medical and sociological literature but none had measured any aspect of health (Connor et al. 1999). A broader search including grey literature for welfare advice delivered in a healthcare setting found 55 studies (one RCT) and concluded that income was improved but could not comment on health (Adams et al. 2006). A third searched medical literature for vocational interventions for unemployed and found weak evidence of no effect on mental health (Audhoe et al. 2010).

Several observational studies have investigated the impact of different policy responses to periods of recession and provide additional pointers to effective interventions. Stuckler et al.'s analysis of the association of changes in unemployment with changes in suicide mortality in 26 European Union countries between 1970 and 2007 indicates that government spending on active labour market programmes mitigated the effect rises in unemployment on suicide (Stuckler et al. 2009). Components of active labour market programmes include classroom or on the job training, job search assistance or sanctions for failing to search, subsidized private sector employment and subsidized public sector employment. Notably, some elements of these programmes were included in the 'job club' (interventions described above) (Caplan et al. 1989; Vinokur et al. 1991a, b, 1995a; Price et al. 1992; Vanryn \& Vinokur, 1992).

Two recent ecological studies conducted during the 2008 recession provide evidence of the beneficial effects of providing generous welfare benefits to people who are out of work. An analysis of US state-level suicide data showed that states providing more generous unemployment benefits experienced lower recessionrelated rises in suicide than those providing less generous welfare support (Cylus et al. 2014). In an ecological analysis of data from 30 countries, there was a graded association between a country's spending on unemployment protection and the effect of unemployment rises on suicide (Norström \& Grönqvist, 2014).

\section{Future research agenda}

Whilst some authors did report their RCTs with reference to CONSORT guidelines (Pleasence \& Balmer, 
2007; Schultz et al. 2010) we would urge authors of future studies to follow this lead to allow accurate assessments of risk-of bias and clarity of analysis and treatment effects (Turner et al. 2012). Some trials had low recruitment rates and, given the likely financial difficulties faced by research participants in this field, trialists could attempt to increase participation by providing incentives or compensation for participants' time, as five of the 11 studies in this review did (see Supplementary Appendix 3).

Recent research into suicides occurring during a period of recession indicated that those whose suicide appeared to be related to consequences of recession were largely still in work, cohabiting, with financial dependents but had no contact with secondary-care psychiatric and little recent contact with primary-care services (Coope et al. 2015). This indicates the need for research into how best to (a) identify those at risk of adverse mental health outcomes during recession, and $(b)$ intervene to reduce risk among those not in contact with services. In the UK's recent recession, policy responses included training front-line job centre and debt collection staff (Fitch \& Davey, 2010; Domokos, 2011). Evaluation of these and similar interventions would inform responses to future recessions. From a healthcare perspective, pragmatic trials in primary care such as the DeCoDer trial will provide useful additional evidence for primary care type interventions to address economic hardship and depression and anxiety (DECODER, 2014). In addition the impact of training primary-care and specialist mental health staff in appraising financial difficulties and signposting them to appropriate statutory and voluntary sector organizations may be worthwhile and form the basis of future evaluative research (Adams et al. 2006; Harris \& Harris, 2009; Barnes et al. 2016). Future RCTs could usefully include measures to help identify what intervention works for whom and why. They might specifically build on work by studies in this review and measure mediating effects e.g. selfefficacy, debt management skills etc. Stratification to create a priori subgroups of participants would help identify which groups were benefitting or not from the intervention. Other potential subgroups could include age, socioeconomic position, or gender. Nested qualitative research could be used to identify potential barriers and facilitators to intervention uptake and adherence among participants and be useful in helping to identify time critical aspects of the intervention, e.g. were participants successful at gaining employment, managing debt, etc. because their mood lifted or vice versa? Researchers could try to publish across both socio-legal and medical disciplines and future systematic reviews should search both literature sources.

\section{Conclusions}

There is reasonably consistent evidence from large RCTs that short, 1- to 2-week 'job club' interventions can reduce depressive symptoms in high-risk, unemployed people up to 2 years. Evidence for CBT is mixed and for other interventions it is limited. Further high-quality RCTs are urgently needed. Such trials might usefully focus on interventions to help individuals with financial difficulties and debt, as most of the literature to date as focussed on provision of help to the unemployed, although the two issues are closely inter-related.

\section{Supplementary material}

The supplementary material for this article can be found at https://doi.org/10.1017/S0033291716002944.

\section{Acknowledgements}

T.H.M.M. and A.R.'s time was supported by the National Institute for Health Research (NIHR) Collaboration for Leadership in Applied Health Research and Care West (CLAHRC West) at University Hospitals Bristol NHS Foundation Trust. D.G., K.H., N.K. and C.M. are supported by NIHR under its Programme Grants for Applied Research scheme (RP-PG-0610-10026). D.G. and K.H. are NIHR senior investigators. The views expressed are those of the authors and not necessarily those of the NHS, the NIHR or the Department of Health.

\section{Declaration of Interest}

D.G., C.M., K.H. and N.K. all report grants from National Institute of Health Research during the conduct of the study; T.H.M.M. and A.R.'s salaries were from NIHR CLAHRC West during the conduct of the study.

\section{References}

Adams J, White M, Moffatt S, Howel D, Mackintosh J (2006). A systematic review of the health, social and financial impacts of welfare rights advice delivered in healthcare settings. BMC Public Health 6, 28.

Audhoe SS, Hoving JL, Sluiter JK, Frings-Dresen MH (2010). Vocational interventions for unemployed: effects on work participation and mental distress. A systematic review. Journal of Occupational Rehabilitation 20, 1-13.

Azrin N (1978). The job-finding club as a method for obtaining employment for welfare-eligible clients: Demonstration, evaluation and counselor training. US Department of labour Report No DLMA-5t-17-76-04. 
Azrin NH, Flores T, Kaplan SJ (1975). Job-finding club: a group-assisted program for obtaining employment. Behaviour Research and Therapy 13, 17-27.

Azrin NH, Philip RA (1979). The job club method for the job handicapped: a comparative outcome study. Rehabilitation Counseling Bulletin 23, 144-155.

Baicker K, Taubman SL, Allen HL, Bernstein M, Gruber JH, Newhouse JP, Schneider EC, Wright BJ, Zaslavsky AM, Finkelstein AN, Oregon Health Study G, Carlson M, Edlund T, Gallia C, Smith J (2013). The Oregon experiment-effects of medicaid on clinical outcomes. New England Journal of Medicine 368, 1713-1722.

Barnes MC, Gunnell D, Davies R, Hawton K, Kapur N, Potokar J, Donovan JL (2016). Understanding vulnerability to self-harm in times of economic hardship and austerity: a qualitative study. BMJ Open bmjopen-2015-010131.

Barr B, Taylor-Robinson D, Stuckler D, Loopstra R, Reeves A, Wickham S, Whitehead M (2015). Fit-for-work or fit-for-unemployment? Does the reassessment of disability benefit claimants using a tougher work capability assessment help people into work? Journal of Epidemiology and Community Health jech-2015-206333.

Burke-Miller J, Razzano LA, Grey DD, Blyler CR, Cook JA (2012). Supported employment outcomes for transition age youth and young adults. Psychiatric Rehabilitation Journal 35, 171-179.

Caplan RD, Vinokur AD, Price RH, van Ryn M (1989). Job seeking, reemployment, and mental health: a randomized field experiment in coping with job loss. Journal of Applied Psychology 74, 759-769.

Chang S-S, Stuckler D, Yip P, Gunnell D (2013). Impact of 2008 global economic crisis on suicide: time trend study in 54 countries. British Medical Journal BMJ 2013;347:f5239.

Connor J, Rodgers A, Priest P (1999). Randomised studies of income supplementation: a lost opportunity to assess health outcomes. Journal of Epidemiology \& Community Health 53, 725-730.

Coope C, Donovan J, Wilson C, Barnes M, Metcalfe C, Hollingworth W, Kapur N, Hawton K, Gunnell D (2015). Characteristics of people dying by suicide after job loss, financial difficulties and other economic stressors during a period of recession (2010-2011): a review of coroners' records. Journal of Affective Disorders 183, 98-105.

Corcoran P, Griffin E, Arensman E, Fitzgerald AP, Perry IJ (2015). Impact of the economic recession and subsequent austerity on suicide and self-harm in Ireland: an interrupted time series analysis. International Journal of Epidemiology 10.1093/ije/dyv058. pp. 969-977.

Craig P, Dieppe P, Macintyre S, Michie S, Nazareth I, Petticrew M (2008). Developing and evaluating complex interventions: the new Medical Research Council guidance. British Medical Journal BMJ 2008;337:a1655.

Cylus J, Glymour MM, Avendano M (2014). Do generous unemployment benefit programs reduce suicide rates? A state fixed-effect analysis covering 1968-2008. American Journal of Epidemiology 180, 45-52.

DECODER (2014). DeCoDer trial debt counselling for depression in primary care: an adaptive randomised controlled trial (Project record). Health Technology Assessment Database 3 HTA-32014000443.

Deeks J, Higgins DJ on behalf of the Cochrane Statistical Methods Group (2010). Statistical algorithms in Review Manager 5.2. The Cochrane Collaboration. pp 1-11. Retrieved from http://ims.cochrane.org/revman/ documentation/Statistical-methods-inRevMan-5.pdf

Derogatis LR, Lipman RS, Rickels K, Uhlenhuth EH, Covi L (1974). The Hopkins Symptom Checklist (HSCL): a self-report symptom inventory. Behavioral Science 19, 1-15.

Domokos J (2011). Jobcentre staff 'sent guidelines on how to deal with claimants' suicide threats'. In The Guardian. The Guardian: UK (https://www.theguardian.com/society/2011/ may/08/jobcentre-staff-guidelines-suicide-threats).

Fernald LC, Hamad R, Karlan D, Ozer EJ, Zinman J (2008) Small individual loans and mental health: a randomized controlled trial among South African adults. BMC Public Health 8, 409.

Finkelstein A, Taubman S, Wright B, Bernstein M, Gruber J, Newhouse JP, Allen H, Baicker K, Or, Oregon Health Study Group (2012). The Oregon health insurance experiment: evidence from the first year. Quarterly Journal of Economics 127, 1057-1106.

Fitch C, Davey R (2010). Debt collection and Mental Health: Ten Steps to Improve Recovery. Royal College of Psychiatrists and the Money Advice Trust: London, p. 20.

Fitch C, Hamilton S, Bassett P, Davey R (2011). The relationship between personal debt and mental health: a systematic review. Mental Health Review Journal 16, 153-166.

Forgatch MS, DeGarmo DS (2007). Accelerating recovery from poverty: prevention effects for recently separated mothers. Journal of Early and Intensive Behavior Intervention 4, 681-702.

Goldberg DP, Gater R, Sartorius N, Ustun TB, Piccinelli M, Gureje O, Rutter C (1997). The validity of two versions of the GHQ in the WHO study of mental illness in general health care. Psychological Medicine 27, 191-197.

Gray D (1983). A job club for older job seekers: an experimental evaluation. Journal of Gerontology 38, 363-368.

Gustafson DJ (1995). Job seeking, reemployment, and mental health: An intervention experiment in coping with job loss. Ph.D. Thesis. California State University: Long Beach.

Harris E, Harris MF (2009). Reducing the impact of unemployment on health: revisiting the agenda for primary health care. Medical Journal of Australia 191, 119-122.

Harris E, Lum J, Rose V, Morrow M, Comino E, Harris M (2002). Are CBT interventions effective with disadvantaged job-seekers who are long-term unemployed? Psychology, Health and Medicine 7, 401-410.

Haw C, Hawton K, Gunnell D, Platt S (2015). Economic recession and suicidal behaviour: possible mechanisms and ameliorating factors. International Journal of Social Psychiatry 61, 73-81.

Higgins J, Altman D, Sterne JAC (2011). Chapter 8: assessing risk of bias in included studies. In Cochrane Handbook for Systematic Reviews of interventions Version 5.1 [updated March 2011] (ed. Higgins JPT and Green S). The Cochrane Collaboration The Cochrane Library (www. cochrane-handbook.org). 
Higgins J, Green S (2011). Cochrane Handbook for Systematic Reviews of interventions Version 5.1 [updated March 2011]. The Cochrane Library, The Cochrane Collaboration (2011). (www.cochrane-handbook.org). The Cochrane Collaboration The Cochrane Library.

Hodzic S, Ripoll P, Bernal C, Zenasni F (2015a). The effects of emotional competences training among unemployed adults: a longitudinal study. Applied Psychology. Health and Well-being 7, 275-292.

Hodzic S, Ripoll P, Lira E, Zenasni F (2015b). Can intervention in emotional competences increase employability prospects of unemployed adults? Journal of Vocational Behavior 88, 28-37.

Jagannathan R, Camasso MJ, Sambamoorthi U (2010). Experimental evidence of welfare reform impact on clinical anxiety and depression levels among poor women. Social Science \& Medicine 71, 152-160.

Joseph LM (1999). The effects of guided mental imagery on subsequent reemployment success in recently laid-off white-collar workers. Dissertation Abstracts International: Section B: The Sciences and Engineering 60, 1337.

Joseph LM, Greenberg MA (2001). The effects of a career transition program on reemployment success in laid-off professionals. Consulting Psychology Journal: Practice $\mathcal{E}$ Research Summer 53, 169-181.

Katikireddi SV, Niedzwiedz CL, Popham F (2012). Trends in population mental health before and after the 2008 recession: a repeat cross-sectional analysis of the 1991-2010 Health Surveys of England. BMJ Open 2 bmjopen-2012-001790.

Kneipp SM, Kairalla JA, Lutz BJ, Pereira D, Hall AG, Flocks J, Beeber L, Schwartz T (2011). Public health nursing case management for women receiving temporary assistance for needy families: a randomized controlled trial using community-based participatory research. American Journal of Public Health 101, 1759-1768.

Kotsou I, Nelis D, Gregoire J, Mikolajczak M (2011). Emotional plasticity: conditions and effects of improving emotional competence in adulthood. Journal of Applied Psychology 96, 827-839.

Kukla M, Bond GR (2009). The working alliance and employment outcomes for people with severe mental illness enrolled in vocational programs. Rehabilitation Psychology 54, 156-163.

Lefebvre C, Mannheimer E, Glanville J, On Behalf of the Cochrane Retrieval Methods Group (2011). Chapter 6: searching for studies. In Cochrane Handbook for Systematic Reviews of Interventions Version 5.1 [updated March 2011]. (ed. Higgins JPT, Green S). The Cochrane Collaboration The Cochrane Library (www.cochrane-handbook.org).

Liberati A, Altman DG, Tetzlaff J, Mulrow C, Gøtzsche PC, Ioannidis JPA, Clarke M, Devereaux PJ, Kleijnen J, Moher D (2009). The PRISMA statement for reporting systematic reviews and meta-analyses of studies that evaluate healthcare interventions: explanation and elaboration. British Medical Journal 339. http://www.bmj. com/content/339/bmj.b2700

Liu S, Huang JL, Wang M (2014). Effectiveness of job search interventions: a meta-analytic review. Psychological Bulletin July 140, 1009-1041.
Moore T, Gunnell D, Metcalfe C, Kapur N, Hawton K (2015). Effects of interventions to ameliorate the impact of unemployment and economic hardship on mental health in the general population. PROSPERO Database. CRD42015019822.

Morris PA, Hendra R (2009). Losing the safety net: how a time-limited welfare policy affects families at risk of reaching time limits. Developmental Psychology 45, 383-400.

Nieuwenhuijsen K, Faber B, Verbeek JH, Neumeyer-Gromen A, Hees HL, Verhoeven AC, van der Feltz-Cornelis CM, Bültmann U (2014). Interventions to improve return to work in depressed people. Cochrane Database of Systematic Reviews 2014, Issue 12. CD006237. DOI: 10.1002/14651858.CD006237.pub3..

Norström T, Grönqvist H (2014). The great Recession, unemployment and suicide. Journal of Epidemiology and Community Health 69, 110-116.

Pleasence P (2008). Trials and tribulations: conducting randomized experiments in a socio-legal setting. Journal of Law and Society 35, 8-29.

Pleasence P, Balmer NJ (2007). Changing fortunes: results from a randomized trial of the offer of debt advice in England and wales. Journal of Empirical Legal Studies 4, 651-673.

Price RH, Van Ryn M, Vinokur AD (1992). Impact of a preventive job search intervention on the likelihood of depression among the unemployed. Journal of Health $\mathcal{E}$ Social Behavior 33, 158-167.

Proudfoot J, Gray J, Carson J, Guest D, Dunn G (1999). Psychological training improves mental health and job-finding among unemployed people. International Archives of Occupational and Environmental Health 72, S40-S42.

Proudfoot J, Guest D, Carson J, Dunn G, Gray J (1997). Effect of cognitive-behavioural training on job-finding among long-term unemployed people. Lancet 350, 96-100.

Rife J (1992). Reducing depression and increasing job placement success of older workers. Clinical Gerontologist 12, 81-85.

Rife JC, Belcher JR (1994). Assisting unemployed older workers to become reemployed: an experimental evaluation. Research on Social Work Practice 4, 3-13.

Salanti G on behalf of the Cochrane Statistical Methods Group. (2013). Statistical algorithms for the Calculator in Review Manager 5.2. The Cochrane Collaboration. RevMan avialable from http://tech.cochrane.org/revman/download

Salman RA-S, Beller E, Kagan J, Hemminki E, Phillips RS, Savulescu J, Macleod M, Wisely J, Chalmers I (2014). Increasing value and reducing waste in biomedical research regulation and management. Lancet 383, 176-185.

Salokangas R, Stengard E, Poutanen O (1994). uusi väline depression torjuntaan [a new screening test for depressive symptoms]. Duodecim 110, 1141-1148.

Schulz KF, Altman DG, Moher D (2010). CONSORT 2010 Statement: updated guidelines for reporting parallel group randomized trials. Annals of Internal Medicine 152, 726-732.

Spera SP, Buhrfeind ED, Pennebaker JW (1994). Expressive writing and coping with job loss. Academy of Management Journal 37, 722-733. 
Stuckler D, Basu S, Suhrcke M, Coutts A, McKee M (2009). The public health effect of economic crises and alternative policy responses in Europe: an empirical analysis. Lancet 374, 315-323.

Tsang HW, Fung KM, Leung AY, Li SM, Cheung WM (2010). Three year follow-up study of an integrated supported employment for individuals with severe mental illness. Australian \& New Zealand Journal of Psychiatry 44, 49-58.

Turner L, Shamseer L, Altman DG, Weeks L, Peters J, Kober T, Dias S, Schulz KF, Plint AC, Moher D (2012).

Consolidated standards of reporting trials (CONSORT) and the completeness of reporting of randomised controlled trials (RCTs) published in medical journals. Cochrane Database of Systematic Reviews 11. doi:10.1002/14651858. MR000030.pub2

Vanryn M, Vinokur AD (1992). How did it work - An examination of the mechanisms through which an intervention for the unemployed promoted job-search behavior. American Journal of Community Psychology 20, 577-597.

van Stolk C, Hofman J, Hafner M, Janta B (2014). Psychological Wellbeing and Work: Improving Service Provision and Outcomes. Department for Work and Pensions and Department of Health: London, UK.

Vinokur AD, Price RH, Caplan RD (1991a). From field experiments to program implementation: assessing the potential outcomes of an experimental intervention program for unemployed persons. American Journal of Community Psychology 71, 166-179.

Vinokur AD, Price RH, Caplan RD (1996). Hard times and hurtful partners: how financial strain affects depression and relationship satisfaction of unemployed persons and their spouses. Journal of Personality \& Social Psychology 71, 166-179.

Vinokur AD, Price RH, Caplan RD, van Ryn M, Curran J (1995a). The Jobs I preventive intervention for unemployed individuals: short- and long-term effects on reemployment and mental health. In Job Stress Interventions, pp. 125-138. American Psychological Association: Washington, DC, USA.

Vinokur AD, Price RH, Schul Y (1995b). Impact of the JOBS intervention on unemployed workers varying in risk for depression. American Journal of Community Psychology 23, 39-74.

Vinokur AD, Schul Y (1997). Mastery and inoculation against setbacks as active ingredients in the JOBS intervention for the unemployed. Journal of Consulting \& Clinical Psychology 65, 867-877.

Vinokur AD, Schul Y, Vuori J, Price RH (2000). Two years after a job loss: long-term impact of the JOBS program on reemployment and mental health. Journal of Occupational Health Psychology 5, 32-47.

Vinokur AD, van Ryn M, Gramlich EM, Price RH (1991b). Long-term follow-up and benefit-cost analysis of the Jobs Program: a preventive intervention for the unemployed. Journal of Applied Psychology 76, 213-219.

Vuori J, Silvonen J (2005). The benefits of a preventive job search program on re-employment and mental health at 2-year follow-up. Journal of Occupational and Organizational Psychology 78, 43-52.

Vuori J, Silvonen J, Vinokur AD, Price RH (2002). The Tyohon job search program in Finland: benefits for the unemployed with risk of depression or discouragement. Journal of Occupational Health Psychology 7, 5-19.

Vuori J, Vinokur AD (2005). Job-search preparedness as a mediator of the effects of the tyohon job search Intervention on re-employment and mental health. Journal of Organizational Behavior 26, 275-291.

Ware Jr. J, Kosinski M, Keller S (1994). SF 36 Physical and Mental Health Summary Scales: A User's Manual. The Health Institute, New England Medical Center.

Watson D, Pennebaker J (1989). Health complaints, stress and distress. Psychological Review 96, 234-254.

WHO (2011). Impact of Economic Crises on Mental Health. Copenhagen, Denmark. p. 34.

WHO (2014). Preventing Suicide: A Global Imperative. WHO: Geneva, Switzerland. p. 92 (http://www.who.int/ mental_health/suicide-prevention/world_report_2014/en/)

WHO (2016). Age-Standardized Suicide Rates (per 100000 population). WHO: Geneva, Switzerland (http://www.who. int/gho/mental_health/suicide_rates/en/).

Wiggins M, Oakley A, Roberts I, Turner H, Rajan L, Austerberry H, Mujica R, Mugford M (2004). The social support and family health study: a randomised controlled trial and economic evaluation of two alternative forms of postnatal support for mothers living in disadvantaged inner-city areas. Health technology assessment (Winchester, England) 8, iii, ix-x, 1-120. 